\title{
Assessment of sediment quality based on acid-volatile sulfide and simultaneously extracted metals in heavily industrialized area of Asaluyeh, Persian Gulf: concentrations, spatial distributions, and sediment bioavailability/toxicity
}

\author{
Hossein Arfaeinia ${ }^{1}$ Iraj Nabipour ${ }^{2} \cdot$ Afshin Ostovar $^{2} \cdot$ Zahra Asadgol $^{1}$ • \\ Ehsan Abuee $^{1,3}$ - Mozhgan Keshtkar ${ }^{4}$ - Sina Dobaradaran ${ }^{4,5,6}$
}

Received: 1 October 2015 / Accepted: 27 January 2016 /Published online: 9 February 2016

(C) Springer-Verlag Berlin Heidelberg 2016

\begin{abstract}
Sediment samples from the coastal area of Asaluyeh harbor were collected during autumn and spring 2015. The acidvolatile sulfide (AVS) and simultaneously extracted metals (SEMs) were measured to assess the sediment quality and potential ecological risks. The average concentrations (and relative standard deviation (RSD)) of AVS in the industrial sediments were $12.32 \mu \mathrm{mol} / \mathrm{g}(36.91)$ and $6.34 \mu \mathrm{mol} / \mathrm{g}(80.05)$ in autumn and spring, respectively, while in the urban area, these values were $0.44 \mu \mathrm{mol} / \mathrm{g}(123.50)$ and $0.31 \mu \mathrm{mol} / \mathrm{g}(160.0)$ in autumn and spring, respectively. The average concentrations of SEM (and RSD) in the industrial sediments were $15.02 \mu \mathrm{mol} / \mathrm{g}(14.38)$ and $12.34 \mu \mathrm{mol} / \mathrm{g}(20.65)$ in autumn and spring, respectively, while in
\end{abstract}

Responsible editor: Céline Guéguen

Sina Dobaradaran

s.dobaradaran@bpums.ac.ir

1 Environmental Health Department, School of Public Health, Iran University of Medical Sciences, Tehran, Iran

2 The Persian Gulf Tropical Medicine Research Center, The Persian Gulf Biomedical Sciences Research Institute, Bushehr University of Medical Sciences, Bushehr, Iran

3 Department of Environmental Health Engineering, Faculty of Public Health, North Khorasan University of Medical Sciences, Bojnurd, Iran

4 Department of Environmental Health Engineering, Faculty of Health, Bushehr University of Medical Sciences, Bushehr, Iran

5 The Persian Gulf Marine Biotechnology Research Center, The Persian Gulf Biomedical Sciences Research Institute, Bushehr University of Medical Sciences, Boostan 19 Alley, Imam Khomeini Street, Bushehr 7514763448, Iran

6 Systems Environmental Health, Oil, Gas and Energy Research Center, The Persian Gulf Biomedical Sciences Research Institute, Bushehr University of Medical Sciences, Bushehr, Iran the urban area, these values were $1.10 \mu \mathrm{mol} / \mathrm{g}(43.03)$ and $1.06 \mu \mathrm{mol} / \mathrm{g}(55.59)$ in autumn and spring, respectively. Zn was the predominant component (34.25-86.24\%) of SEM, while the corresponding value for $\mathrm{Cd}$, much more toxic ingredient, was less than $1 \%$. Some of the coastal sediments in the harbor of Asaluyeh (20 and $47 \%$ in autumn and spring, respectively) had expected adverse biological effects based on the suggested criterion by United States Environmental Protection Agency (USEPA), while most stations (80 and $53 \%$ in autumn and spring, respectively) had uncertain adverse effects.

Keywords Acid-volatile sulfide $\cdot$ Simultaneously extracted metal $\cdot$ Heavy metal $\cdot$ Sediment $\cdot$ Asaluyeh harbor

\section{Introduction}

In aquatic ecosystems, inorganic and organic pollutants have been introduced via natural geochemical processes and anthropogenic activities (Cesar et al. 2006). These areas are often regions of elevated population densities and centralized human activities (Gan et al. 2013; Mucha et al. 2005). As a result, high levels of pollutants in sediments reflect the effects of industrialization and urbanization (Celino et al. 2008; Raj and Jayaprakash 2008). Sediments are considered to be the main sinks for organic and trace metal elements for the coastal environment (Burton et al. 2005; Wang and Chapman 1999). Many of the discharged metallic pollutants have deposited in the sediments; however, when environmental conditions $(\mathrm{pH}$, redox potential, and others) change, settled metals in sediments may break free to the water, making the sediments act as an internal source of trace metals (Morgan et al. 2012; Morse and Rickard 2004; Van Den Berg et al. 1999). Heavy metals are considered as one of the most serious contaminants 
of the ecosystem due to their bioaccumulation, biomagnifications, and even increasing the exposure of human (Prica et al. 2008; Yang et al. 2012). Thus, the contents of these pollutants in sediments are often monitored to provide information for the evaluation of environmental health risks (Gao and Chen 2012; Gao et al. 2013; Long et al. 1995).

Recently, much consideration has been given to the acidvolatile sulfide (AVS) model as an appropriate procedure to evaluate the quality of sediment. AVS can assess the potential risks of heavy metals correctly with the further advantages such as high efficiency, simple utilization, and batch processing (Allen et al. 1993; Brouwer and Murphy 1994; De Lange et al. 2008). AVS is considered as one of the main chemical constituents of marine sediments that plays a significant role in controlling the speciation and the environmental risks of heavy metals in the sediments and its interstitial waters (Casas and Crecelius 1994; Cooper and Morse 1998; Prica et al. 2008), while simultaneously extracted metals (SEMs) refers to sulfide-bound metals extracted in the AVS extraction procedure (mostly including copper $(\mathrm{Cu})$, cadmium $(\mathrm{Cd})$, lead $(\mathrm{Pb})$, nickel (Ni), and zinc ( $\mathrm{Zn})$ ) (Di Toro et al. 1990; Li et al. 2014a). In ecosystem studies, the sum of the molar concentrations of SEM $(\mu \mathrm{mol} / \mathrm{g})$ in comparison with AVS $(\mu \mathrm{mol} / \mathrm{g})$ was suggested as an important indicator to evaluate the bioavailability and potential ecological risk of heavy metals (Berry et al. 1996; Di Toro et al. 1990). When SEM-AVS is higher than 0 or the ratio of SEM/AVS is higher than 1, acute toxicity of heavy metals may be occurred whereas the generation of acute toxicity is less possible when SEM-AVS is lower than 0 or the ratio of SEM/AVS is lower than 1 (Ankley 1996; Di Toro et al. 1990, 2005). But, it should be noted that when SEM-AVS is higher than 0 or the ratio of SEM/AVS is higher than 1, heavy metal toxicity can be overestimated. In this condition, other components in sediment such as total organic compounds (TOCs) can also bind to free metal ions, which may decrease their bioavailability and, consequently, reduce their toxicity (Burton et al. 2005; Ingersoll et al. 2002; Spencer et al. 2006). A modified AVS approach was suggested regarding the total organic carbon (TOC) in sediments $\left(f_{\mathrm{OC}}\right)$, and it has been approved to be more appropriate than the previous approach (De Jonge et al. 2010, 2012a, b; Keene et al. 2010; Zhuang and Gao 2013). Moreover, other researchers have demonstrated that AVS concentrations could have both spatial and seasonal changes, and this variation has been known as a problem in using AVS approach to evaluate metal bioavailability in sediments (Campana et al. 2009; Oehm et al. 1997; Poot et al. 2007).

Asaluyeh $\left(26^{\circ} 30^{\prime}-27^{\circ} 50^{\prime} \mathrm{N}, 51^{\circ} 01^{\prime}-52^{\circ} 81^{\prime} \mathrm{N}\right)$ is a city and the capital of Asaluyeh County, in Bushehr Province, Iran, and is located on the seafront of the Persian Gulf approximately $270 \mathrm{~km}$ southeast of the provincial capital of Bushehr (Iran; Mokhtarani et al. 2006a, b). It is well known as the site for the land-based facilities of the huge Pars Special Energy
Economic Zone (PSEEZ) project. The PSEEZ as it is known has been allocated $100 \mathrm{~km}^{2}$ of land at Asaluyeh for the numerous enterprises and industries. The site is a collection of various petrochemical refineries and industries and is administered by the PSEEZ agency onsite (Iran; Mokhtarani et al. 2006a, b). A total of 27 phases are envisaged (12 gas, 15 petrochemical), plus a mix of light and heavy industry, and associated support facilities such as factories and warehouses (Iran; Mokhtarani 2006a, b). The scale of the project is huge. Since 1900s, explosive industrialization and rapid expansion of the population have contributed to the elevated industrial and municipal wastewater release in this area (Iran; Mokhtarani et al. 2006a, b). This phenomenon led to serious concerns about the pollution problems in the Asaluyeh coastal areas.

Heavy metals as one of the main contaminants may accumulate in the sediments and lead to increase the potential toxicity of the sediments (De Jonge et al. 2010). Therefore, it is important to monitor and understand heavy metal bioavailability and their toxicity in the Asaluyeh coastal areas. There are sporadic studies on heavy metal contaminations in the coastal areas of the Persian Gulf (Monikh et al. 2013, 2015); however, they were only focused on the total amount of trace metals. Although AVS and SEM are good environmental indicators, but to the best of our knowledge, there is no report yet on heavy metals in the marine sediments based on the AVS and SEM analysis in the region of the Persian Gulf. So, in this study, we selected the harbor of Asaluyeh (with the world's largest gas field shared between Iran and Qatar) in the northern part of the Persian Gulf (Azin et al. 2010) and aimed (1) to determine the concentrations of heavy metals in the marine sediments throughout the Asaluyeh harbor based on the AVS and SEM analysis and (2) to evaluate spatial distribution of heavy metals and their potential toxicity and ecological risk. In addition, data were obtained from urban and industrial areas of Asaluyeh harbor during spring and autumn seasons to assess the spatial distribution effects.

\section{Materials and methods}

\section{Sediment sample collection}

The surveys were conducted during two phases in 20142015: middle autumn to early winter (November-December 2014 henceforth referred to as autumn for short) that was prior the peak period of the rainfall season and early to middle spring (April-May 2015, henceforth referred to as spring for short), that was after the peak period of the rainfall season. Eleven sediment sampling stations were arranged near the urban area (hereafter referred to as UST), and ten sediment sampling stations were arranged near the industrial area (hereafter referred to as IST) in the Asaluyeh harbor (Fig. 1). All 


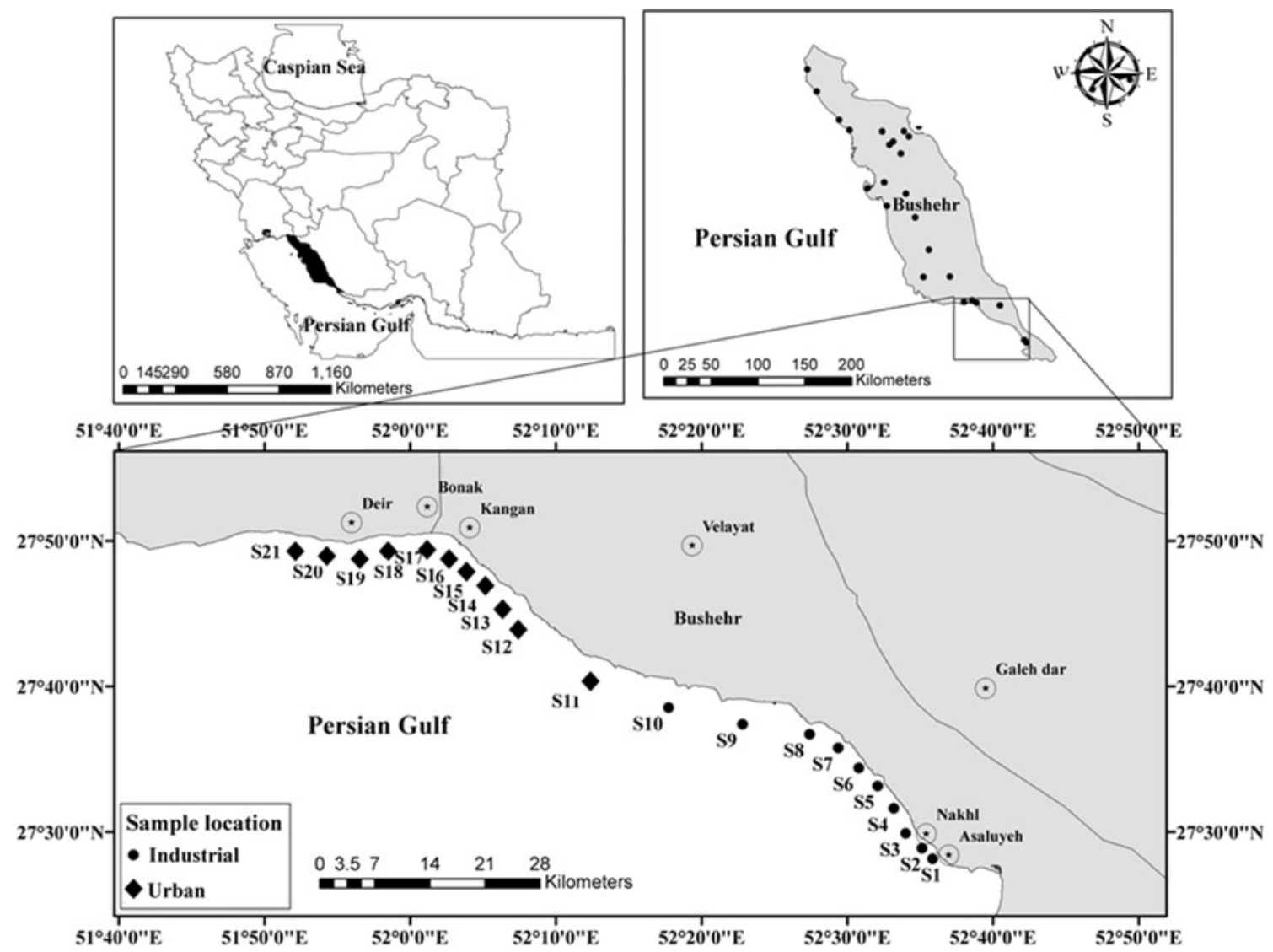

Fig. 1 The study area and sampling stations

sampling stations were located in the marine region except one which was located in estuary of Khoor River. Sampling stations were selected based on collecting representative sediment samples that would cover the entire harbor water evenly and represent possible contaminant sources. So, a general assessment of contaminant concentrations of harbor sediments could be efficiently done. All devices and materials for sediment sampling, cleanup, and storage were accurately selected and properly treated to minimizing the anthropogenic pollution of the samples (USEPA 2004b). Exact location of each sampling station was identified using global positioning system (GPS). Sample collection, preservation, and storage were done based on EPA methods for collection, storage, and manipulation of sediments for chemical and toxicological analyses technical manual 2001 (USEPA 2001). The Ekman steel grab sampler $\left(25 \times 25 \times 25 \mathrm{~cm}^{3}\right)$ was used to collect the surface sediments. A total of 42 samples (including 21 samples in autumn and 21 samples in spring) were collected. Since the sulfide ion is unstable in the presence of oxygen, for analysis of the AVS, sediment samples were collected according to EPA guideline to protect samples from exposure to oxygen during the sample collection and storage process (EPA 2010). So, instantly after sampling, sediment samples from each station were placed in the polyethylene zipper bag with no head space or with full of high-purity nitrogen gas $\left(\mathrm{N}_{2}\right)$, which have been pre-washed and kept in an icebox, then brought back to the laboratory (EPA 2010). In the laboratory, sediment samples were frozen at $-20{ }^{\circ} \mathrm{C}$ within $12 \mathrm{~h}$ until further analysis.

\section{Sample analysis}

\section{Analysis of general characteristics of sediments}

The $\mathrm{pH}$ and redox potential (Eh) of each sample were measured in situ immediately after sampling procedure using a U50 multi-parameter water quality checker (HORIBA, Germany). The moisture content (MC) was determined by comparing the wet weight with the dry weight at before and after drying at $105^{\circ} \mathrm{C}$ for $24 \mathrm{~h}$, respectively.

Since the concentration of trace metals in sediments depends forcefully on its granule size distribution and its correlation with organic matter, size distribution and TOC content of samples were measured in order to a well interpretation and explanation of the mobility and availability of metals (Fernandes et al. 2011). CHN analyzer (Perkin-Elmer, model $2400 \mathrm{CHN}$ ) was used to measuring the TOC content. Particle size analyzer (Mastersizer 2000, Malvern, Britain) capable of analyzing particle sizes between 0.02 and $2000 \mu \mathrm{m}$ was used to analyze the size distribution of sediment samples. The 
percentages of the three ranges of particle sizes including $<2 \mu \mathrm{m}$ (clay), 4-75 $\mu \mathrm{m}$ (silt), and $>75 \mu \mathrm{m}$ (sand) Gao and Chen (2012) were also determined.

\section{AVS analysis}

The general procedure for measuring of AVS in this study was based on a modified diffusion technique (Van Griethuysen et al. 2002). Several researchers reported that CuS phases of AVS cannot be completely extracted with $1 \mathrm{M} \mathrm{HCl}$, and this issue may possibly lead to underestimation in the AVS concentrations of sediment samples (De Jonge et al. 2012a; Simpson et al. 1998). So, for every $3 \mathrm{~g}$ of each wet sediment sample, $5 \mathrm{~mL}$ of $6 \mathrm{M}$ hydrochloric acid $(\mathrm{HCl})$ was used for extraction of AVS and SEM. Ten milliliter sulfide antioxidant buffer (SAOB) solution that contained $0.2 \mathrm{M}$ ascorbic acid, $2 \mathrm{M}$ $\mathrm{NaOH}$, and $0.2 \mathrm{M}$ disodium EDTA was used to collect the volatile hydrogen sulfide $\left(\mathrm{H}_{2} \mathrm{~S}\right)$ in which the free sulfur ion content was determined using an ion specific electrode (De Jonge et al. 2012a; Van Griethuysen et al. 2002). This electrode was calibrated with a $0.1 \mathrm{M} \mathrm{Na}_{2} \mathrm{~S}$ solution diluted in SAOB, in a concentration range of $10^{-4}-10^{-2} \mathrm{M}$. This covers the range of AVS concentrations in the SAOB, liberated from the sediment samples. The molarity of the $\mathrm{Na}_{2} \mathrm{~S}$ stock solution used for the calibration was measured daily by back titration with $0.02 \mathrm{M}$ sodium thiosulfate after complexation with $0.02 \mathrm{M}$ iodine.

After determination of the $\mathrm{S}^{-2}$ ion concentration, the SAOB solution was eliminated with a pipette and disposed off. Part of the sediment extract was filtered on $0.45-\mu \mathrm{m}$ membrane filters with a water jet pump. The first $10 \mathrm{ml}$ were used to rinse the $50 \mathrm{ml} \mathrm{PE}$ bottles and their caps and were discarded; the next $20 \mathrm{ml}$ of filtrate was collected and placed in centrifuges for $20 \mathrm{~min}$ at $3000 \mathrm{rpm}$, and henceforth, the supernatant of these extractions were used for determination of $\mathrm{SEM}(\mathrm{Cu}, \mathrm{Pb}, \mathrm{Zn}, \mathrm{Ni}$, and $\mathrm{Cd})$.

In these analyses, apparatus blanks, calibration curves, reagent blanks, and standard recoveries were employed. A standard sodium sulfide was used to checking the recovery rate and calibration the AVS method by developing a calibration curve (Allen et al. 1993; Hinkey and Zaidi 2007). Quality assurance of AVS extraction was controlled by calibrating the procedure versus specified amounts of $\mathrm{Na}_{2} \mathrm{~S} \cdot 9 \mathrm{H}_{2} \mathrm{O}$ (Durán et al. 2012), and recovery rates were within 86$96 \%$, showing high performance method of extraction. Duplicate measurements were made as a part of the quality assurance, and the relative standard deviations of the AVS and SEM were below the $10 \%$.

\section{SEM analysis}

The concentrations of SEM $(\mathrm{Cu}, \mathrm{Pb}, \mathrm{Zn}, \mathrm{Ni}$, and $\mathrm{Cd})$ were quantified by using inductively coupled plasma atomic emission spectroscopy (ICP-AES, Arcos model, Germany). Stock standard solutions containing $50 \mathrm{mg} / \mathrm{l}$ for $\mathrm{Pb}$ and $\mathrm{Zn}, 20 \mathrm{mg} / \mathrm{l}$ for $\mathrm{Cu}, 5.0$ for $\mathrm{Ni}$, and $2.0 \mathrm{mg} / \mathrm{l}$ for $\mathrm{Cd}$ applied for preparing working standards. The analysis was operated with radiofrequency power of $1250 \mathrm{~W}$. Delay time was $28 \mathrm{~s}$, and the flow rate of nebulizer, plasma, auxiliary, and sample gas were 0.9 , $15,0.2$, and $1.6 \mathrm{l} / \mathrm{min}$, respectively. The detection limit (mg/ $\mathrm{kg}$ ) and wavelength $(\mathrm{nm})$ of heavy metal analyzed were 0.006 and 206.2 for $\mathrm{Zn}, 0.008$ and 267.7 for Ni, 0.05 and 221.4 for $\mathrm{Pb}, 0.004$ and 222.8 for $\mathrm{Cd}$, and 0.007 and 321.4 for $\mathrm{Cu}$, respectively. All materials (tubes, bottles, etc.) were washed and cleaned by acid before using, and all reagents were guaranteed or analytical grade.

\section{Biotoxicity assessment of heavy metal}

Two approaches published by the United States Environmental Protection Agency (USEPA) and one approach suggested by Di Toro et al. (2005) were applied for evaluation of heavy metal biotoxicity in this research: SEMAVS (USEPA 2004a), (SEM-AVS) $/ f_{\text {OC }}$ (USEPA 2005b), and (SEM-AVS) $/ f_{\text {OC }}$ (Di Toro et al. 2005).

\section{Statistical analysis}

The normality of all data was checked with the Shapiro-Wilk test before analyzing. The Spearman correlation coefficient was performed to compare the relationship between AVS, SEM, and other variables in pairs. A paired samples $t$ test $(P<0.05)$ was used to determine whether seasonal variations had significant effect on AVS and SEM, respectively. These analyses were done and calculated with the SPSS statistical package version 19.0 (SPSS Inc.). Also, ArcMap 10.2 geographical information system (GIS) (ESRI, Redlands, CA) was applied as a suitable tool for mapping and the Raster Calculator of the ArcGIS Spatial Analyst extension to render to estimate concentration of pollutants anywhere that all of the predictors can be measured in the sediments of Asaluyeh harbor along the Persian Gulf. The ArcMap 10.2 (GIS) was also used to kriging interpolations of the SEM, AVS, and TOC concentrations.

\section{Results and discussion}

\section{Distribution of physical-chemical parameters of sediments}

Figure 2a, b shows the sediment composition of Asaluyeh harbor in the industrial and urban areas during autumn and spring. As shown in Fig. 2a, in autumn, clay content (the mineral fraction of grains less than $2 \mu \mathrm{m}$ ) ranged from 1.74 to $19.65 \%$ with an average value of $10.52 \%$ in the industrial area and 1.98 to $21.65 \%$ with an average value of $10.10 \%$ in 

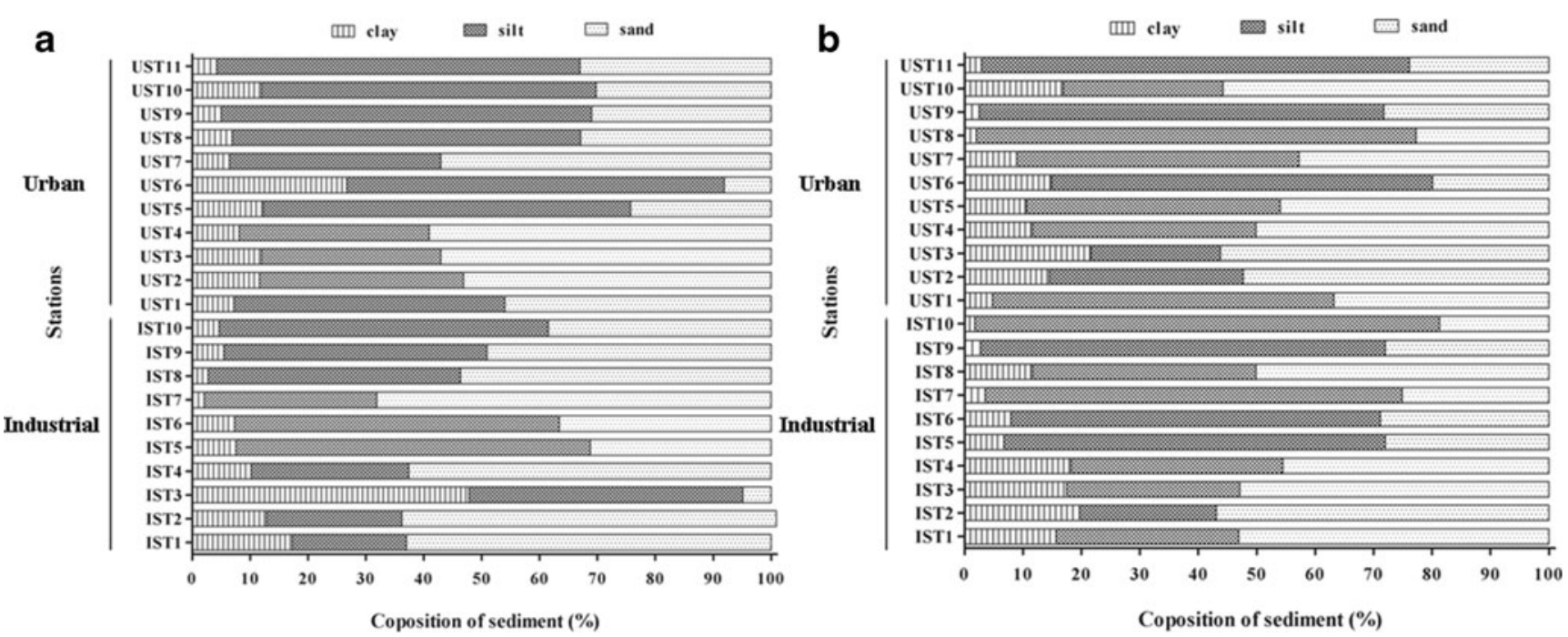

Fig. 2 The composition of coastal sediment samples collected from Asaluyeh harbor in the autumn (a) and spring (b)

the urban area. Silt (the fraction of grains between 2 and $75 \mu \mathrm{m}$ ) ranged from 23.43 to $79.52 \%$ with an average value of $50.74 \%$ in the industrial area and 22.15 to $75.30 \%$ with an average value of $50.36 \%$ in the urban area. Sand content (the fraction of grains greater than $75 \mu \mathrm{m}$ ) ranged from 18.74 to $65.92 \%$ with an average value of $40.54 \%$ in the industrial area and 19.93 to $56.20 \%$ with an average value of $39.52 \%$ in the urban area. In spring, the content of clay, silt, and sand varied from 2.11 to $47.84 \%, 19.65$ to $62.21 \%$, and 4.88 to $68.11 \%$, respectively, with their respective average values of $11.80,41.05$, and $47.23 \%$ in the industrial area (Fig. 2b). In addition, the content of clay, silt, and sand varied from 4.20 to $26.70 \%, 26.6$ to $73.42 \%$, and 4.09 to $73.09 \%$, respectively, with their respective average values of $10.91,54.33$, and $40.13 \%$ in the urban area during spring (Fig. 2b). It reveals that the textures of the sediments in the harbor of Asaluyeh were dominantly consisting of slit and sand. However, there is no previously published report on distribution of physicalchemical parameters of sediments in the harbor of Asaluyeh for comparison with results of the present study. Some researchers also found similar findings regarding size distribution of sediments in other parts of the world stating that it mainly composed of coarse-grained fractions ( $\mathrm{Hu}$ et al. 2011; Qiao et al. 2010). They attributed these results to the combined effects of anti-clockwise circulation and tidal fluctuations which caused the fine surface sediments near the mouth of estuaries to be re-suspended and then carrying them to the central of the gulf (Jiang et al. 2000; Qiao et al. 2010). This explanation may also be applicable in the case of Asaluyeh.

Figure 3 depicts the moisture content (MC) variations in the sediments of Asaluyeh harbor. In the industrial area, MC ranged from 22.73 to $51.59 \%$ with an average value of $36.69 \%$ in autumn; the corresponding data were 12.99 64.23 and $37.03 \%$ in spring, respectively. In the urban area,
MC ranged from 10.93 to $64.04 .59 \%$ with an average value of $31.70 \%$ in autumn; the corresponding data were 12.23 77.3 and $41.86 \%$ in spring, respectively. The TOC concentrations in the sediment are shown in Table 1 and Fig. 4. In the industrial area, the TOC values ranged from 0.26 to $1.62 \%$ with an average value of $0.92 \%$ in autumn and 0.4 to $3.21 \%$ with an average value of $1.40 \%$ in spring, respectively. In the urban area, the TOC values ranged from 0.05 to $1.55 \%$ with an average value of $0.34 \%$ in autumn and $0.17-2.56 \%$ and with an average value of $0.88 \%$ in spring, respectively. The increased pattern of TOC contents from autumn to spring indicated the increased bioactivity and bioaccumulation in the water system (Zhuang and Gao 2013). UST16 had the highest TOC concentration in both seasons of autumn and spring (IST6 in autumn and IST1 in spring were exceptions). The sediment collected from UST16 (the estuary of a Khoor River) received large amounts of municipal wastewater which is rich in organic matter. Similar results were reported by $\mathrm{Li}$ et al. (2014a) for Leizhou Peninsula located in South China Sea. Moreover, the average value of TOC content in the industrial stations was more than the urban stations, in general. These findings showed that anthropogenic activities and industrial zone represent the main sources of sediment TOC contents and can exert a substantial influence on carbon cycling processes in coastal sediments (Zimmerman and Canuel 2000). Effects on carbon cycling and the ecology of the marine ocean are also possible to the extent that coastal productivity may be subsequently exported (Zimmerman and Canuel 2000).

Figures 5 and 6 demonstrate the redox potential (Eh) and $\mathrm{pH}$ of sediments, respectively. In the industrial area, Eh ranged from -412 to $146 \mathrm{mV}$ with an average value of $-155 \mathrm{mV}$ in autumn, and the corresponding data were -421 to $149 \mathrm{mV}$ and $-169 \mathrm{mV}$ in spring, respectively. In the urban area, Eh ranged from -287 to $157 \mathrm{mV}$ with an average value of $-63 \mathrm{mV}$ in 
Fig. 3 The moisture content in urban and industrial stations of the coastal sediments of Asaluyeh harbor in autumn and spring

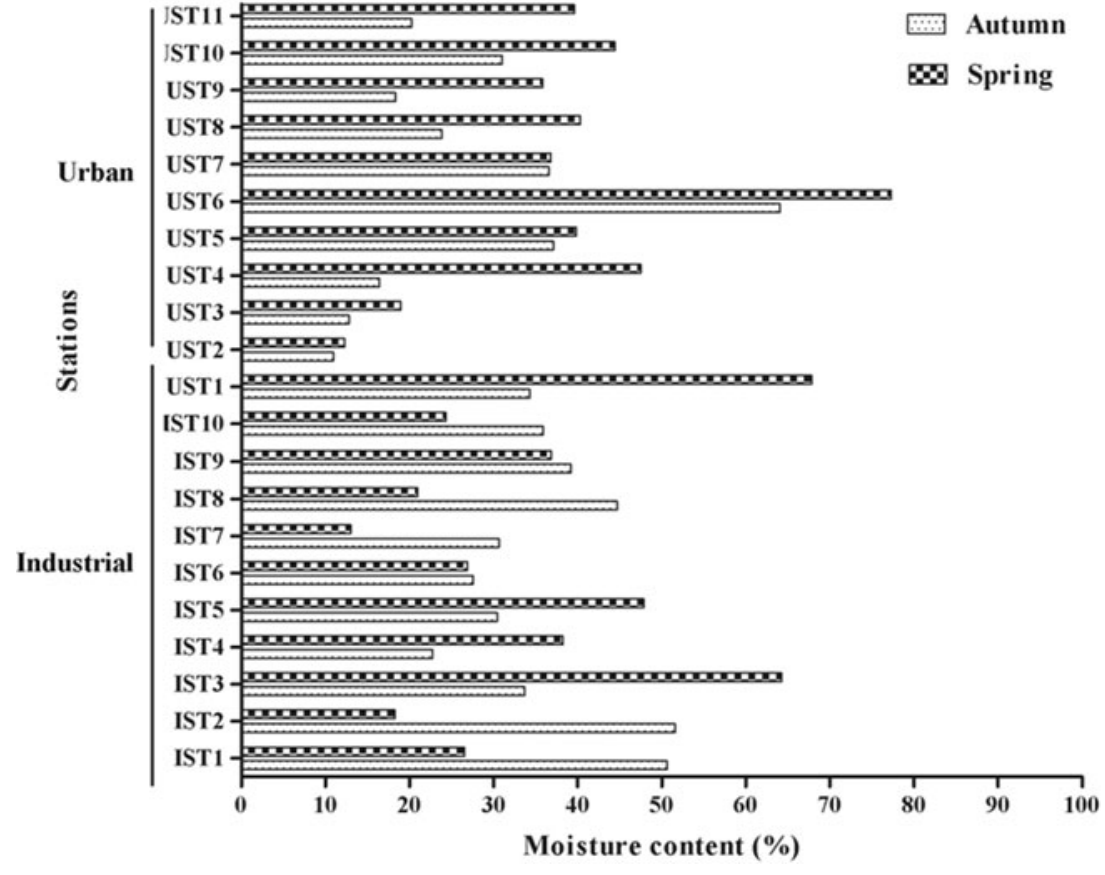

autumn, and the corresponding data were -287 to $141 \mathrm{mV}$ and $-92 \mathrm{mV}$ in spring, respectively. Besides, this industrial stations had higher AVS contents and generally lower redox potentials in comparison with the urban stations. Eh values in both seasons of autumn and spring changed widely among sampling stations and have a slightly increased pattern from autumn to spring in general. The importance of Eh for the biological and chemical processes in the marine sediments has been confirmed before (Becking et al. 1960; Berner 1963). Bacterial sulfate reduction takes place only in environments with negative redox potentials, as shown in many pure culture studies (Davis and Yarbrough 1966). Therefore, it is generally expected that stations with negative redox potentials contain higher AVS concentrations in contrast to stations with positive redox potentials.

In the industrial area, the values of $\mathrm{pH}$ changed from 5.41 to 7.94 with an average value of 6.96 in autumn, and the corresponding data were 6.63-8.19 and 7.35 in autumn, respectively. In the industrial area, the values of $\mathrm{pH}$ changed from 6.98 to 7.41 with an average value of 7.13 in autumn, and the corresponding data were 7.22-7.91 and 7.6 in autumn, respectively. $\mathrm{pH}$ is the dominating mobilizing factor for metals in sediments (Calmano et al. 1993). It is reported that decomposition of organic matter may lead to decrease the value of $\mathrm{pH}$ due to the formation of humic acid (Nobi et al. 2010) and consequently increase the metal release. On the other hand, the higher values of $\mathrm{pH}$ can reduce the reduction rate of $\mathrm{SO}_{4}{ }^{2-}$ through the inhibition of activity and growth of sulfate reducing bacteria (SRB) (Hou et al. 2013). Our findings also demonstrated that stations with higher concentrations of AVS and SEM had lower $\mathrm{pH}$ compare with other stations. Nevertheless, there is no apparent variation in $\mathrm{pH}$ values of sediment due to the presence of carbonates, which are regarded as effective buffer agent (Du Laing et al. 2009).

\section{Spatial distribution of AVS in sediments}

The AVS concentrations in the sediment samples of Asaluyeh harbor were shown in Fig. 7, and associated information is summarized in Table 1. The average values of AVS concentrations in the industrial sediments were 12.32 and $6.34 \mu \mathrm{mol} /$ $\mathrm{g}$ in autumn and spring, respectively, and the relative standard deviations (RSDs) were up to 36.91 and 80.05 , respectively. In the urban area, the average value of AVS concentrations were 0.44 and $0.31 \mu \mathrm{mol} / \mathrm{g}$ in autumn and spring, respectively, and RSD values were 123.50 and 160.0 , respectively.

Generally, AVS concentrations in the sediments of industrial area, which is the area with more frequent anthropogenic activities, were much higher than those in the urban sediments, and the differences between AVS concentrations of sediments in the industrial were also greater than those in the urban area. This can be attributed to the waste discharge from industrial effluents. In a recent study, higher AVS concentrations in sediments of rivers which received industrial and domestic discharges were also reported (Zhuang and Gao 2013). UST16 had the highest mean AVS concentration between all urban stations in both seasons of autumn and spring, which was sediment collected from the estuary of a Khoor River. This river was close to the pisciculture and aquaculture areas for fish and shellfish. Asami et al. (2005) have previously reported that pisciculture and aquaculture industry may accelerate sulfur accumulation; therefore, high 
Table 1 The summary of AVS and SEM contents in sediments collected from the coastal areas in Asaluyeh harbor

\begin{tabular}{|c|c|c|c|c|c|c|c|c|c|c|}
\hline Sampling season & Area & Descriptive statistics & TOC & AVS & SEM & $\mathrm{Cd}$ & $\mathrm{Cu}$ & $\mathrm{Ni}$ & $\mathrm{Pb}$ & $\mathrm{Zn}$ \\
\hline \multirow[t]{16}{*}{ Autumn } & \multirow[t]{8}{*}{ Urban } & $\operatorname{Min}(\mu \mathrm{mol} / \mathrm{g})$ & 0.09 & 0.017 & 0.42 & 0.00010 & 0.13 & 0.0012 & 0.012 & 0.23 \\
\hline & & $\operatorname{Max}(\mu \mathrm{mol} / \mathrm{g})$ & 1.55 & 1.70 & 2.09 & 0.00065 & 0.76 & 0.01 & 0.080 & 1.61 \\
\hline & & Mean $(\mu \mathrm{mol} / \mathrm{g})$ & 0.38 & 0.44 & 1.10 & 0.00033 & 0.33 & 0.006 & 0.035 & 0.74 \\
\hline & & SD & 0.40 & 0.54 & 0.48 & 0.00018 & 0.17 & 0.0032 & 0.02 & 0.36 \\
\hline & & RSD (\%) & 107.04 & 123.5 & 2.09 & 52.87 & 53.99 & 53.97 & 59.37 & 48.78 \\
\hline & & $\operatorname{Min}(\%)$ & & & & 0.009 & 17.11 & 0.16 & 1.24 & 48.29 \\
\hline & & $\operatorname{Max}(\%)$ & & & & 0.12 & 47.06 & 1.12 & 6.62 & 78.32 \\
\hline & & Mean $(\%)$ & & & & 0.04 & 30.08 & 0.58 & 3.32 & 65.98 \\
\hline & \multirow[t]{8}{*}{ Industrial } & $\operatorname{Min}(\mu \mathrm{mol} / \mathrm{g})$ & 0.27 & 8.22 & 11.64 & 0.0021 & 2.12 & 0.09 & 0.43 & 6.78 \\
\hline & & $\operatorname{Max}(\mu \mathrm{mol} / \mathrm{g})$ & 1.62 & 19.74 & 20.15 & 0.0057 & 6.34 & 0.98 & 1.14 & 12.43 \\
\hline & & Mean $(\mu \mathrm{mol} / \mathrm{g})$ & 0.92 & 11.62 & 15.02 & 0.0038 & 4.14 & 0.55 & 0.86 & 9.47 \\
\hline & & $\mathrm{SD}$ & 0.37 & 3.68 & 2.16 & 0.0010 & 1.41 & 0.32 & 0.23 & 1.97 \\
\hline & & RSD (\%) & 40.42 & 31.69 & 14.38 & 26.29 & 33.92 & 58.52 & 26.94 & 20.76 \\
\hline & & Min (\%) & & & & 0.014 & 14.23 & 0.62 & 3.71 & 47.61 \\
\hline & & $\operatorname{Max}(\%)$ & & & & 0.040 & 40.17 & 7.48 & 7.78 & 77.68 \\
\hline & & Mean (\%) & & & & 0.026 & 27.55 & 3.82 & 5.68 & 62.93 \\
\hline \multirow[t]{16}{*}{ Spring } & \multirow[t]{8}{*}{ Urban } & $\operatorname{Min}(\mu \mathrm{mol} / \mathrm{g})$ & 0.17 & 0.04 & 0.23 & 0.00005 & 0.078 & 0.0005 & 0.009 & 0.13 \\
\hline & & $\operatorname{Max}(\mu \mathrm{mol} / \mathrm{g})$ & 2.56 & 1.74 & 2.52 & 0.00085 & 1.63 & 0.007 & 0.12 & 0.94 \\
\hline & & Mean $(\mu \mathrm{mol} / \mathrm{g})$ & 0.71 & 0.29 & 1.07 & 0.0003 & 0.376 & 0.0026 & 0.032 & 0.66 \\
\hline & & SD & 0.68 & 0.47 & 0.59 & 0.00024 & 0.43 & 0.002 & 0.035 & 0.26 \\
\hline & & RSD (\%) & 96.53 & 159.9 & 55.61 & 78.95 & 113.8 & 71.30 & 108.01 & 39.64 \\
\hline & & $\operatorname{Min}(\%)$ & & & & 0.084 & 10.08 & 0.0044 & 0.76 & 34.25 \\
\hline & & $\operatorname{Max}(\%)$ & & & & 0.75 & 64.91 & 0.28 & 8.05 & 86.24 \\
\hline & & Mean $(\%)$ & & & & 0.29 & 30.52 & 0.05 & 3.04 & 66.11 \\
\hline & \multirow[t]{8}{*}{ Industrial } & $\operatorname{Min}(\mu \mathrm{mol} / \mathrm{g})$ & 0.40 & 1.07 & 9.37 & 0.001 & 1.32 & 0.02 & 0.36 & 4.65 \\
\hline & & $\operatorname{Max}(\mu \mathrm{mol} / \mathrm{g})$ & 3.21 & 18.89 & 17.96 & 0.034 & 5.64 & 0.78 & 1.04 & 11.34 \\
\hline & & Mean $(\mu \mathrm{mol} / \mathrm{g})$ & 1.41 & 6.34 & 12.35 & 0.006 & 3.35 & 0.40 & 0.71 & 7.9 \\
\hline & & SD & 0.84 & 5.08 & 2.56 & 0.0093 & 1.35 & 0.31 & 0.22 & 1.93 \\
\hline & & RSD (\%) & 59.86 & 80.06 & 20.66 & 142.64 & 40.31 & 77.74 & 30.52 & 24.39 \\
\hline & & $\operatorname{Min}(\%)$ & & & & 0.18 & 10.53 & 0.01 & 3.84 & 45.36 \\
\hline & & $\operatorname{Max}(\%)$ & & & & 7.27 & 43.32 & 0.27 & 10.14 & 83.21 \\
\hline & & Mean $(\%)$ & & & & 3.32 & 26.97 & 0.53 & 5.7 & 63.95 \\
\hline
\end{tabular}

The unit is $\mu \mathrm{mol} / \mathrm{g}$ dry sediment weight for all parameters

concentration of AVS may be related to the aquaculture process in this area. Two probable reasons for this phenomenon can be explained by (1) a great deal of uneaten food and fish excretion generated by excessive fish farming and aquacultures that cause accumulation of organic matter (including the compound of C, N, P, S) in sediments (Yokoyama et al. 2004) and (2) anaerobic conditions caused by high organic matter that will also accelerate the process of sulfate reduction (Asami et al. 2005). The anaerobic conditions usually happen in the sediments in fish farming areas where the cages prevent the water exchange and oxygen often deplete by organic matter ( $\mathrm{Li}$ et al. 2014a). Moreover, the higher concentrations of AVS in UST16 might be attributed to the relatively higher TOC and finer grains in this station and to the rich terrigenous incoming and anoxia condition in Khoor River (Zhuang and Gao 2013). Machado et al. (2008) stated that high TOC content and fine particle size in sediment can cause hypoxia condition due to oxidation of organic matter and low oxygen retrieval and afterward provide an appropriate condition for SRB that can reduce sulfate to sulfide.

The AVS concentration of sediment may change with several factors such as TOC content, Eh, MC, presence of clay, silt, and sand, and other variables, which influence the sulfate reduction rate (Prica et al. 2008). Spearman correlation analysis for the sediment constituents in this study are depicted in Table 2. This analysis showed that the AVS concentration is significantly and positively correlated with the MC, clay, and silt contents and negatively correlated with sand $(P<0.05)$ in 


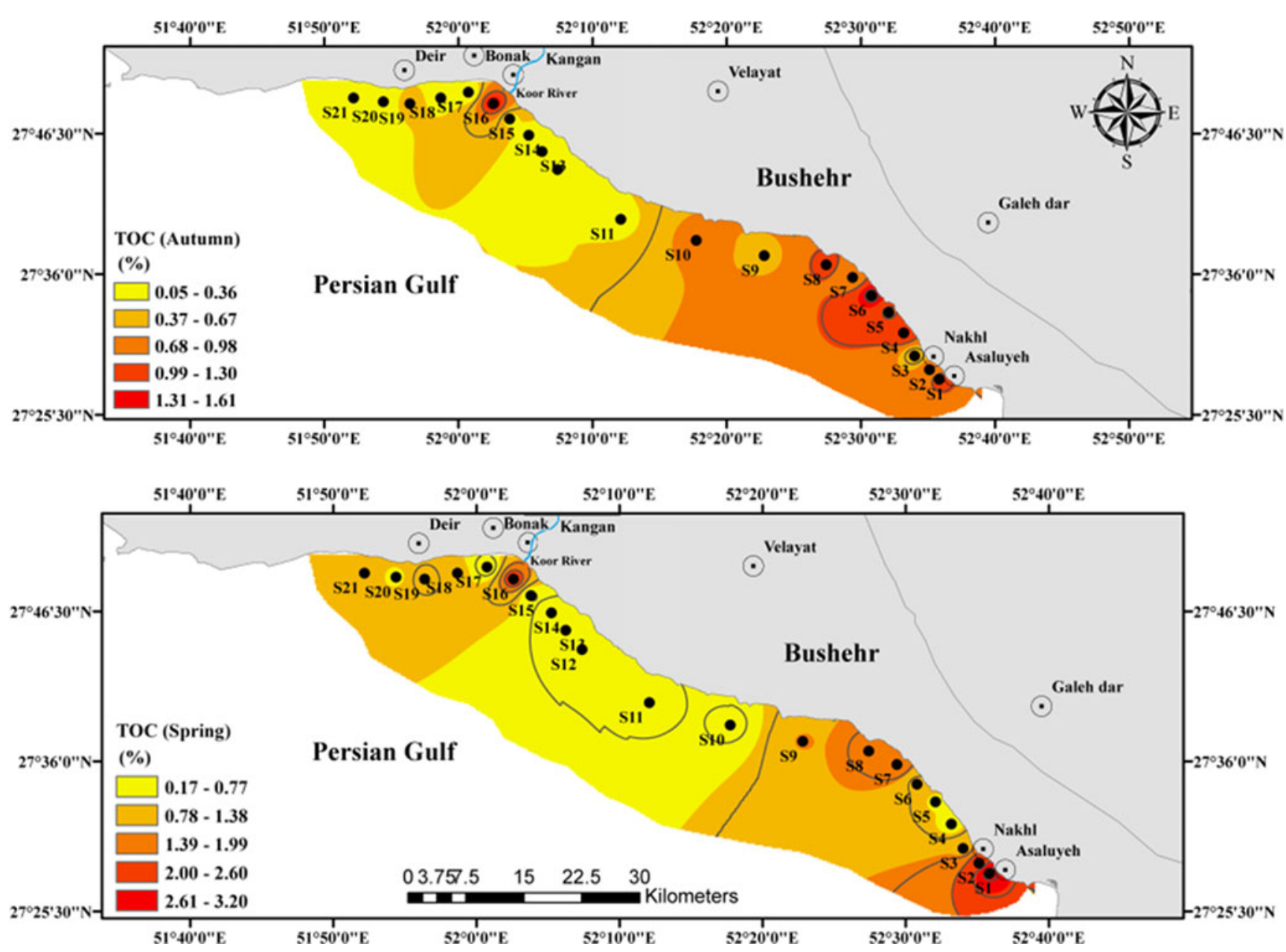

Fig. 4 The comparison of spatial distribution of TOC in autumn and spring in the coastal sediments of Asaluyeh in Persian Gulf

Fig. 5 The Eh in urban and industrial stations of the coastal sediments of Asaluyeh harbor in autumn and spring

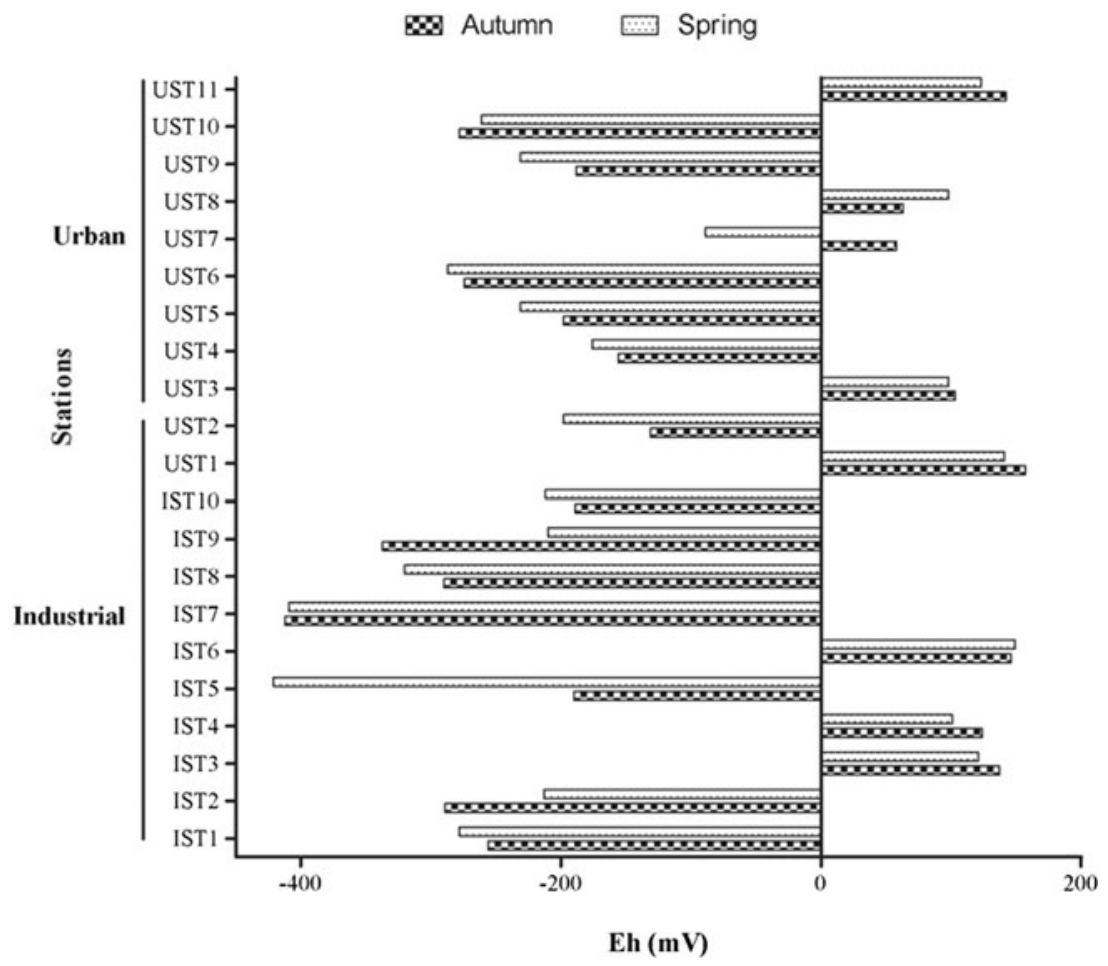


Fig. 6 The $\mathrm{pH}$ in urban and industrial stations of the coastal sediments of Asaluyeh harbor in autumn and spring

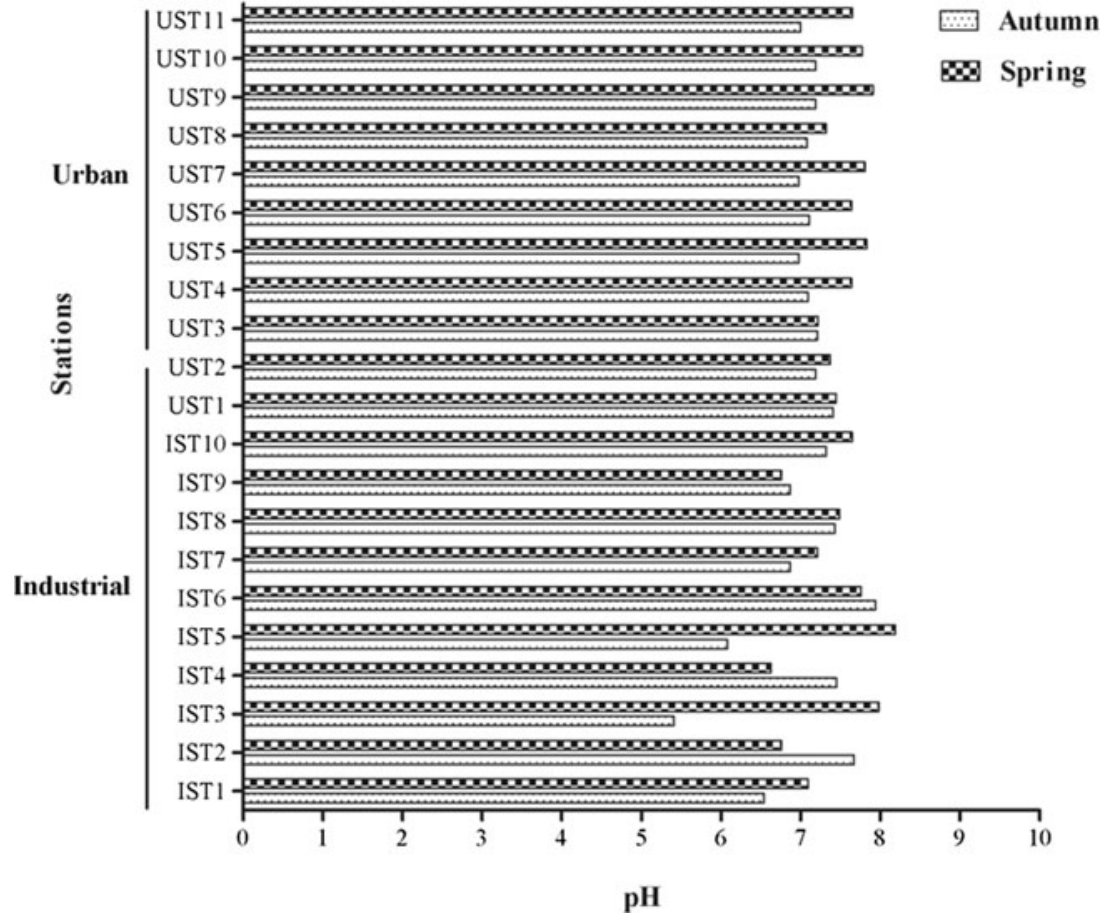

both seasons of autumn and spring, suggesting that fine fraction of sediment grains, higher TOC, and higher moisture contents favor conditions for AVS formation in overall. The AVS concentration is also significantly and positively correlated with the TOC content $(0.001<P<0.01)$ in autumn, which was consistent with the results of former studies in the Leizhou Peninsula (South China Sea) and off-shore area of Laizhou Bay (Li et al. 2014a). However, in spring, AVS concentration had no significant correlation with TOC content. TOC content had an increased pattern from autumn to spring; thus, TOC probably was a main limitation factor for the formation of AVS in autumn. Some other researches also revealed that AVS concentrations were not necessarily significantly correlated with TOC content (Fang et al. 2005; Liu et al. 2007).

The higher AVS concentrations were found at stations IST5 and IST7 (autumn and spring), IST8 (spring), and UST16 and UST20 (autumn and spring) (Fig. 7). The mean values of Eh at these stations were lower than $-200 \mathrm{mV}$, particularly in IST5 and IST7 whose Eh values were even lower than $-400 \mathrm{mV}$ (spring) (Fig. 5). Sediments collected from these stations had severe anoxia conditions. AVS concentration was significantly and negatively correlated with $\mathrm{Eh}(P<0.001)$ in both seasons of autumn and spring, which proved the relationship between AVS and the redox potential in the sediments of Asaluyeh harbor (Table 2).

The AVS concentrations ranged from 0.02 to $22.24 \mu \mathrm{mol} / \mathrm{g}$ with an average value of $6.09 \mu \mathrm{mol} / \mathrm{g}$ in autumn. The corresponding data were $0.04-18.89$ and $3.17 \mu \mathrm{mol} / \mathrm{g}$ in spring, respectively. The increased pattern of AVS contents from autumn to spring could be attributed to severe metabolism of
SRB with plentiful organic material as carbon and energy sources in autumn (Zhuang and Gao 2013). Good evidence for this phenomenon is the increased pattern of the TOC from autumn to spring (Fig. 4).

Among all sampling stations, only sediment samples of stations IST5, UST13, UST14, UST17, and UST18 had higher AVS concentration levels in spring compared with autumn. AVS concentration levels at all the other 16 stations decreased from autumn to spring (Fig. 7). Van Griethuysen et al. (2006) have reported that $\mathrm{O}_{2}$ saturation and SRB activities had significant roles in the AVS formation and degradation. It has been also reported that AVS can exist close to the interface of sediment-water during hypoxia, while it was simply oxidized under oxic status (Wijsman et al. 2001). In spring, the wind was more severe on the sea than in autumn, and waves were much higher that may cause the raise in the content of oxygen dissolving and then oxidizing the AVS. In some stations in our study, increase of Eh values was found from spring to autumn (Fig. 5). The majority of SRB are mesophilic or thermophilic bacteria with optimum temperature ranges from 25 to $40{ }^{\circ} \mathrm{C}$ (Morita 1975) and are sensitive to temperature variations (Castro et al. 2000). To date, no information is available for the harbor of Asaluyeh sediments to show whether or not SRB plays a significant role in the AVS concentration variations, and further studies are needed in this area to make it clear.

The paired samples $t$ test was used to assess the correlation between AVS concentrations of the two sampling periods. There was no significant correlation between AVS concentrations of the two sampling periods in both industrial and urban sediments $(P>0.05$; Table 3$)$ and it appeared that the AVS 


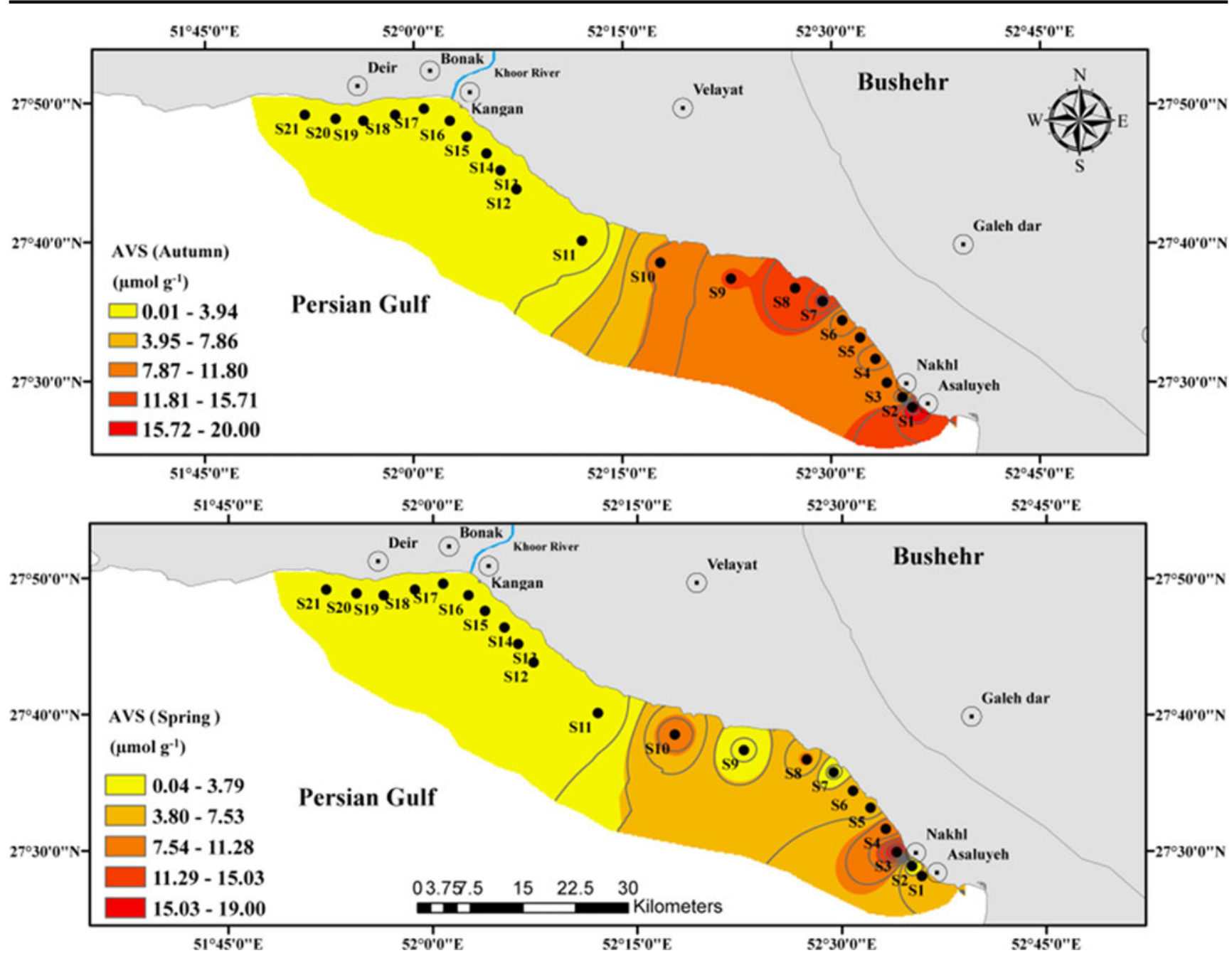

Fig. 7 The comparison of spatial distribution of AVS in autumn and spring in the coastal sediments of Asaluyeh harbor in Persian Gulf

concentration was not related to seasonal changes. It also has been reported that AVS concentrations did not simply depend on seasonal variation (Zhuang and Gao 2013). It should be noted that the production and stability of AVS in the sediments are complicated and scarce studies directly examined the effect of seasonal variation on AVS contents of sediments, and further studies should be performed in order to explain this issue.

The comparison between the AVS concentrations of the present study and the findings from other similar researches in other regions are presented in Table 4. Compared with coastal areas of the other regions, the AVS concentrations in this study were wider than those recorded in Laizhou Bay (Gao et al. 2013), Shen'ao Bay (Du et al. 2011), Zhangjiang Estuary, Fujian (Jingchun et al. 2010), Pearl River Estuary (Fang et al. 2005), Jinzhou Bay (Hansen et al. 1996), Futian mangrove, Shenzhen Bay (Chai et al. 2015), Huanghe Estuary (Wu et al. 2007), north area of the Bohai Bay (Jiang et al. 2005), Yangze River Estuary (Sun et al. 2009), Mudflat, Zhangjiang Estuary (Jingchun et al. 2010), Zhangjiang Estuary (Jingchun et al. 2010), and southern East China Sea continental slope (Lin et al. 2002). All of these studies did not perform in industrial and high-polluted areas; hence, it is expected to have lower concentration levels of AVS compared with this study that was conducted in heavily industrialized area. The AVS concentrations in this research were narrower than the corresponding values in Jiaozhou Bay sediments (Huo et al. 2001) with high AVS concentration in mariculture region that can be due to high sulfur production because of organic matter accumulation and anaerobic conditions. In addition, higher concentration levels of AVS were reported in lagoons (Burullus, Maryut, and Manzalah) (Younis et al. 2014). Cited lagoons received untreated and poorly treated wastewater, and consequently, they were exposed to high inputs of pollutants from industrial, domestic, and agricultural sources.

\section{Spatial distribution of SEM in sediments}

Figure 8 represents the spatial distribution of SEM (which is the sum of the $\mathrm{Cu}, \mathrm{Zn}, \mathrm{Pb}, \mathrm{Cd}$, and $\mathrm{Ni}$ concentrations) in sediments, and associated information is provided in 
Table 2 Pearson correlation coefficients between the measured parameters of surface sediment samples collected from the coastal areas in Asaluyeh harbor

\begin{tabular}{|c|c|c|c|c|c|c|c|c|c|c|c|c|c|c|}
\hline Sampling season & Parameters & AVS & SEM & $\mathrm{Cd}$ & $\mathrm{Cu}$ & $\mathrm{Ni}$ & $\mathrm{Pb}$ & $\mathrm{Zn}$ & $\% \mathrm{TOC}$ & $\% \mathrm{MC}$ & $\%$ Clay & $\%$ Silt & $\%$ Sand & Eh \\
\hline \multirow[t]{7}{*}{ Autumn } & AVS & 1 & 0.747 & 0.312 & 0.494 & 0.434 & 0.539 & 0.564 & 0.729 & 0.512 & 0.362 & 0.411 & -0.273 & -0.712 \\
\hline & SEM & & 1 & 0.597 & 0.698 & 0.628 & 0.619 & 0.418 & 0.567 & 0.506 & 0.524 & 0.673 & -0.521 & -0.428 \\
\hline & $\mathrm{Cd}$ & & & 1 & 0.236 & 0.165 & 0.289 & 0.202 & 0.136 & 0.118 & 0.043 & 0.212 & -0.181 & -0.112 \\
\hline & $\mathrm{Cu}$ & & & & 1 & 0.562 & 0.529 & 0.506 & 0.289 & 0.332 & 0.413 & 0.397 & 0.012 & -0.254 \\
\hline & $\mathrm{Ni}$ & & & & & 1 & 0.682 & 0.398 & 0.412 & 0.584 & 0.171 & 0.129 & -0.482 & -0.391 \\
\hline & $\mathrm{Pb}$ & & & & & & 1 & 0.487 & 0.322 & 0.754 & 0.120 & 0.127 & -0.076 & -0.213 \\
\hline & $\mathrm{Zn}$ & & & & & & & 1 & 0.317 & 0.587 & 0.059 & 0.089 & -0.319 & -0.274 \\
\hline \multirow[t]{7}{*}{ Spring } & AVS & 1 & 0.739 & 0.278 & 0.528 & 0.397 & 0.543 & 0.576 & 0.187 & 0.714 & 0.393 & 0.514 & -0.336 & -0.389 \\
\hline & SEM & & 1 & 0.548 & 0.712 & 0.744 & 0.472 & 0.447 & -0.113 & 0.774 & 0.647 & 0.723 & -0.619 & -0.523 \\
\hline & $\mathrm{Cd}$ & & & 1 & 0.512 & 0.427 & 0.412 & 0.332 & -0.087 & 0.388 & 0.329 & 0.418 & -0.728 & -0.410 \\
\hline & $\mathrm{Cu}$ & & & & 1 & 0.719 & 0.524 & 0.418 & -0.105 & 0.621 & 0.589 & 0.591 & -0.492 & -0.443 \\
\hline & $\mathrm{Ni}$ & & & & & 1 & 0.739 & 0.584 & -0.087 & 0.739 & 0.693 & 0.782 & -0.638 & -0.393 \\
\hline & $\mathrm{Pb}$ & & & & & & 1 & 0.523 & -0.065 & 0.812 & 0.725 & 0.718 & -0.798 & -0.388 \\
\hline & $\mathrm{Zn}$ & & & & & & & 1 & -0.113 & 0.639 & 0.514 & 0.583 & -0.711 & -0.432 \\
\hline
\end{tabular}

Table 1. The average values of SEM concentrations in the industrial sediments were 15.02 and $12.34 \mu \mathrm{mol} / \mathrm{g}$ in autumn and spring, respectively, and the RSDs were up to 14.38 and 20.65 , respectively. In the urban area, the average values of SEM concentrations were 1.10 and $1.06 \mu \mathrm{mol} / \mathrm{g}$ in autumn and spring, respectively, and RSD values were 43.03 and 55.59, respectively. Extremely high contents of SEM in industrial areas can be probably explained with discharge from factories (Wang and Wang 2007). In our study, various petrochemical refineries and industries are located near the sampling stations in the industrial area, and an outfall was observed

Table 3 The paired samples $t$ test analysis of the dependence of AVS and SEM between the sampling seasons

\begin{tabular}{llll}
\hline Area & Parameters & $P$ value & $\begin{array}{l}\text { Significant difference } \\
\text { at level 0.05 }\end{array}$ \\
\hline Industrial & AVS & 0.785 & No \\
& SEM & 0.812 & No \\
& $\mathrm{Cd}$ & 0.332 & No \\
& $\mathrm{Cu}$ & 0.493 & No \\
& $\mathrm{Ni}$ & 0.121 & No \\
& $\mathrm{Pb}$ & 0.491 & No \\
& $\mathrm{Zn}$ & 0.219 & No \\
Urban & $\mathrm{AVS}$ & 0.063 & No \\
& $\mathrm{SEM}$ & $6.12 \times 10^{-7}$ & Yes \\
& $\mathrm{Cd}$ & $1.37 \times 10^{-5}$ & Yes \\
& $\mathrm{Cu}$ & $5.42 \times 10^{-6}$ & Yes \\
& $\mathrm{Ni}$ & $7.23 \times 10^{-3}$ & Yes \\
& $\mathrm{Pb}$ & $6.39 \times 10^{-6}$ & Yes \\
& $\mathrm{Zn}$ & 0.005 & Yes \\
\hline
\end{tabular}

in the upstream about dozens of meters away from sampling stations, but it cannot be specified to which chemical factory it belongs. Researches demonstrated that human building metals were more weekly bound to sediment particles and may be freed back to the water phase with the variation of physical and chemical parameters such as $\mathrm{pH}$, Eh, salinity, and TOC (Soares et al. 1999). Thus, contamination risk of anthropogenic heavy metals is too much.

In general, the mean values of SEM had a decreased pattern from autumn to spring in sampling stations but seemed to increase in Khoor River sediments. In both seasons of autumn and spring, the highest mean value of SEM concentration among the urban stations was observed in the Khoor River sediments, and this was in compatible with AVS, denoting the effect of anthropogenic activities, waste discharge from municipal and industrial effluents, and surface runoff on the heavy metal contents (Gao et al. 2013; Wang and Wang 2007).

The predominance of $\mathrm{Zn}$ over all the other four acidextracted metals was obvious in all samples and accounted for nearly $34.25-86.24 \%$ of the total SEM content, while the corresponding value for much more toxic one, $\mathrm{Cd}$, was less than $1 \%$ (Fig. 9, Table 1). On average, in the sediments of Asaluyeh harbor, the levels of SEM components increased in the order of $\mathrm{Cd}<\mathrm{Pb}<\mathrm{Ni}<\mathrm{Cu}<\mathrm{Zn}$ (Fig. 9). These findings are in agreement with the results of former reported studies (Gao et al. 2013) but are inconsistent with another study (Hu et al. 2012); the chemical features of metal sulfides are certainly a substantial factor and contribute to this inconsistence. Metal sulfides have various solubility as a function of their pKsp amounts $\mathrm{CuS}>\mathrm{CdS}>\mathrm{PbS}>\mathrm{ZnS}>\mathrm{NiS}$, that mainly influences the capability of metals in sediment to formation SEM (Gao et al. 2013). Moreover, the following biogeochemical parameters perhaps also are responsible for this 


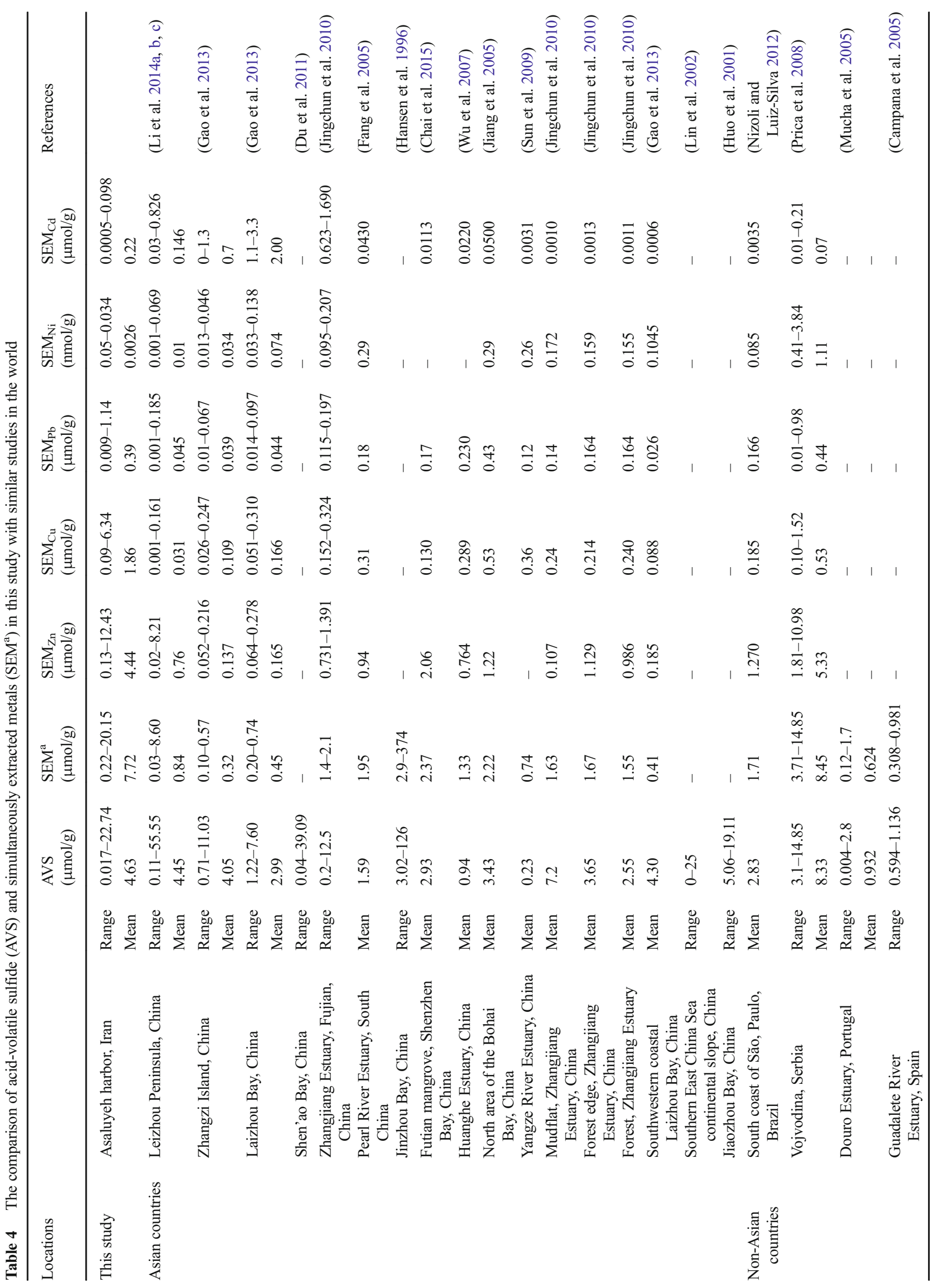




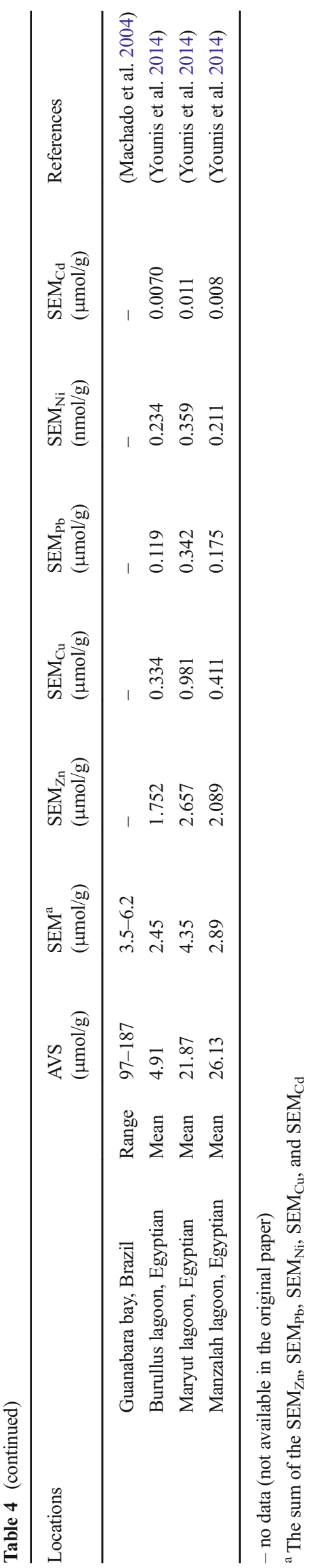

inconsistence: the type of sediment based on the factors that influence metal action and reaction with sediment matrix, $\mathrm{pH}$, nutrient conditions, cationic exchange capacity, TOC and carbonate contents, redox status, and texture, the environmental factors that may cause weathering such as redox processes, acidification, temperature, and water regime (Gao et al. 2013).

It has been said that AVS seems to have the precedency to sorption with SEM; however, Fe-Mn oxyhydroxide, organic compound, and carbonate may be significant linkage phases in sediments (Yu et al. 2001). Acid-volatile sulfide is operationally procedure that is utilized to extract AVS, may meantime attack organic matter and Fe-Mn oxyhydroxides to a lower degree (Yu et al. 2001). Thus, the extracted SEM may also contain $\mathrm{Fe}-\mathrm{Mn}$ oxyhydroxide and organic matter-bound metals (Fang et al. 2005; Yu et al. 2001). Therefore, the SEM distribution may have different pattern from that of AVS, and the remarkable difference found might show the different metal partitioning in the sediments.

As shown in Table 2, the SEM concentration is also significantly and positively correlated with the TOC content $(0.001<P<0.01)$ in autumn; however, in spring, AVS concentration did not significantly correlated with TOC content. There was also significant positive correlations between components of SEM (except Cd) and TOC in autumn $(P<0.001)$, but this was not true in spring (Table 2). These findings implied that TOC might be one of the main carriers of SEM as important as AVS in autumn, but SEM might be majorly composed of AVS or other materials in spring (Zhuang and Gao 2013). Significant positive correlations in both seasons of autumn and spring were found between components of SEM in pairs (Table 2), which show that these heavy metals were related with each other and might have common natural and anthropogenic origin such as discharged wastewater, particularly from industrial areas (Feng et al. 2004; Hu et al. 2012; Wang and Wang 2007). Also, there were significant positive relationships between all simultaneously extracted metals and $\mathrm{MC}$, clay, and silt but significant negative relationships with sand in spring as AVS did, indicating the similar formative and existing status of AVS and SEM in this period (Table 2).

Although, the fine fraction of sediment particles (clay + silt) indicated nonsignificant positive correlations with $\mathrm{Zn}$, $\mathrm{Pb}$, and $\mathrm{Ni}$ in autumn (Table 2), which was in agreement with the findings of Ip et al. study in the estuary of Pearl River and its surrounding coastal area, in China (Ip et al. 2007). They concluded that the levels of trace metals in sediments could not be easily explained by variations in particle size.

The paired samples $t$ test revealed that there was significant correlation between SEM concentrations of the two sampling periods in the urban sediments $\left(6.12 \times 10^{-7}<P<0.005\right)$ but not in the industrial sediments. This appeared that the SEM concentration is not only related to seasonal variations but also other factors are involved in the concentration level of SEM. In a recent study, Zhuang et al. also reported that seasonal 


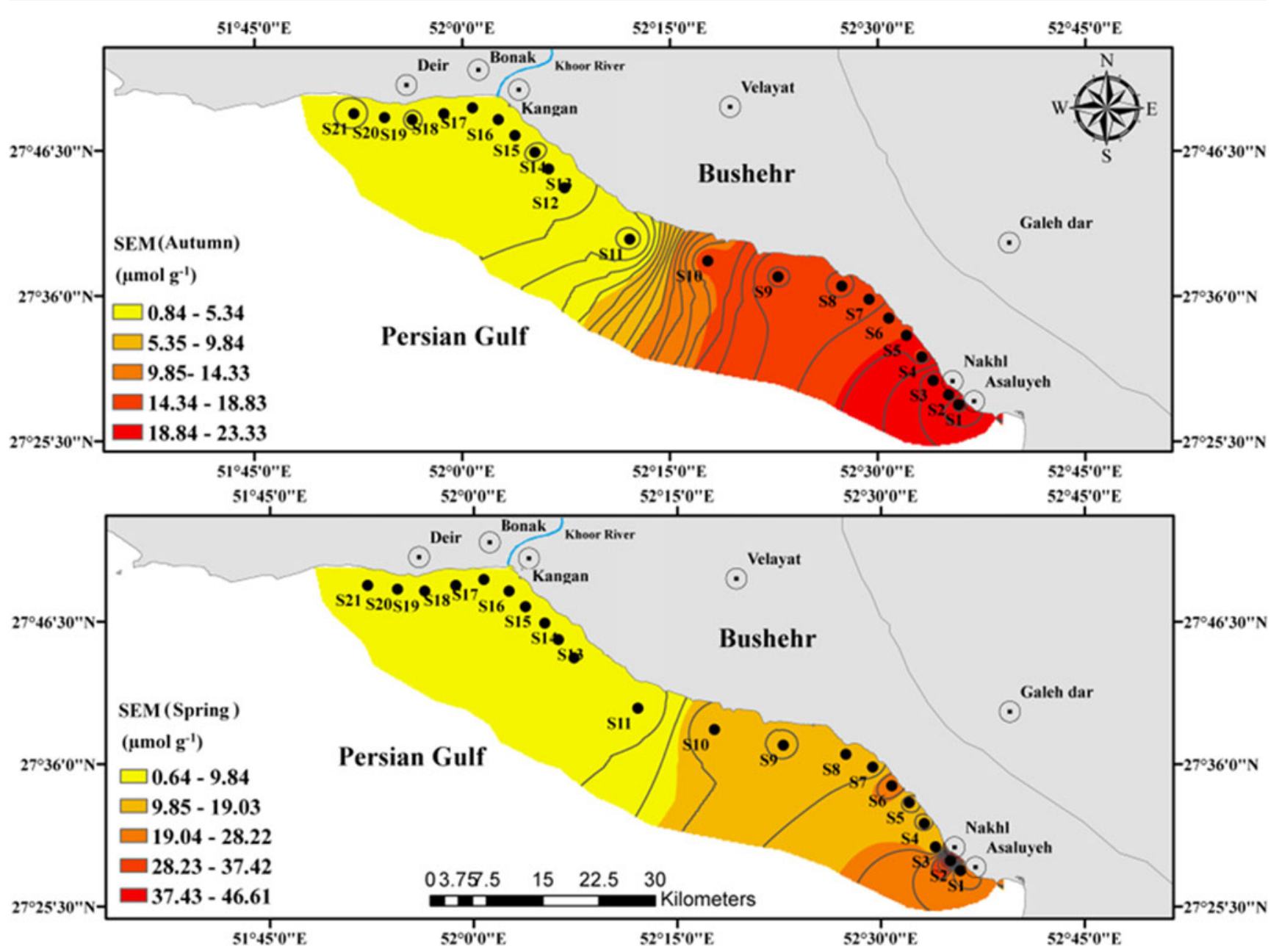

Fig. 8 The comparison of spatial distribution of SEM in autumn and spring in the coastal sediments of Asaluyeh harbor in Persian Gulf

variations had no effect on SEM concentration levels in river sediment and pointed out that other factors such as variability in terrestrial inputs, hydrodynamic process, and deposition conditions, besides seasonal changes, might influence the distribution characteristics of SEM in sediments of rivers
(Zhuang and Gao 2013). On the other hand, Mucha et al. (2005) showed that only concentration of $\mathrm{Al}$ and $\mathrm{Ni}$ had clear seasonal patterns, presenting the highest in spring or fall and the lowest in winter or summer, and for all other metals (including $\mathrm{Fe}, \mathrm{Mn}, \mathrm{Zn}, \mathrm{Cu}, \mathrm{Cr}, \mathrm{Pb}$, and $\mathrm{Cd}$ ), no clear pattern were found.

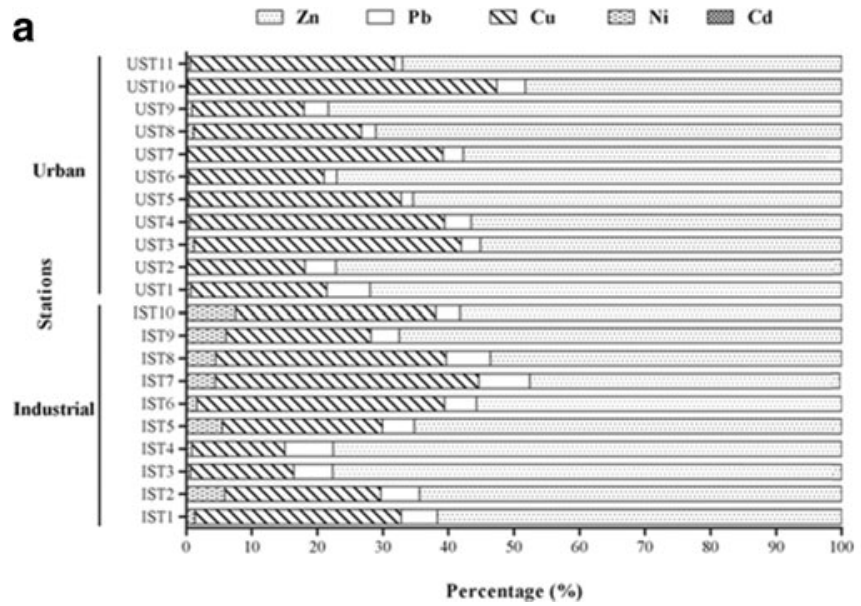

b

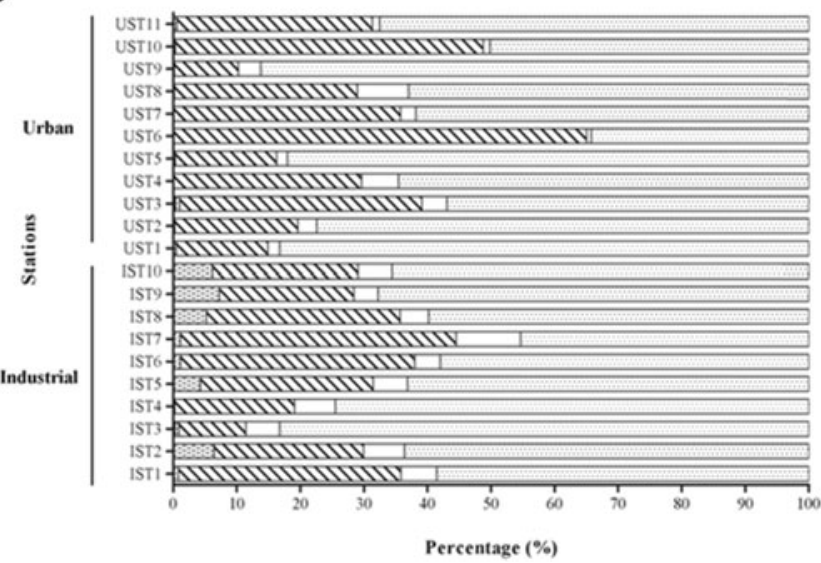

Fig. 9 The percentage of heavy metals in the coastal sediments of Asaluyeh harbor in a autumn and $\mathbf{b}$ spring 
The results of SEM showed approximately similar contents of AVS in the Asaluyeh harbor compared with the data obtained by Prica et al. (2008) in Vojvodina, Serbia, and Younis et al. (2014) in Maryut kagoon, Egypt, as shown in Table 4. Prica et al. (2008) mentioned that nonpurified or insufficiently purified wastewaters which discharged to the watercourses were the main important diffuse sources of pollution being agriculture. Younis et al. studied the lagoon Maryut that suffers from almost all possible environmental problems and to quite an extreme degree from various sources, industrial and urban untreated sewage (Qalaa and Umum drains). The findings of SEM were higher than the corresponding values for the sediments in Leizhou Peninsula (Li et al. 2014a, b, c), Zhangzi Island, southwestern coastal Laizhou Bay and Laizhou Bay (Gao et al. 2013), Shen'ao Bay (Du et al. 2011), Zhangjiang Estuary, Fujian (Jingchun et al. 2010), Pearl River Estuary (Fang et al. 2005), Jinzhou Bay (Hansen et al. 1996), Futian mangrove, Shenzhen Bay (Chai et al. 2015), Huanghe Estuary (Wu et al. 2007), north area of the Bohai Bay (Wu et al. 2007), Yangze River Estuary (Sun et al. 2009), Mudflat, Zhangjiang Estuary (Jingchun et al. 2010), Forest edge (Jingchun et al. 2010), Zhangjiang Estuary (Jingchun et al. 2010), Forest, Zhangjiang Estuary (Jingchun et al. 2010), southern East China Sea continental slope (Gao et al. 2013), and Jiaozhou Bay (Huo et al. 2001), all in China. The results in the present study were also higher than those recorded in the south coast of São Paulo in Brazil (Nizoli and Luiz-Silva 2012), Douro Estuary in Portugal (Mucha et al. 2005), Guadalete River Estuary in Spain (Campana et al. 2005), and lagoons (Burullus and Manzalah) in Egypt (Younis et al. 2014). All of these studies did not perform in industrial and high-polluted areas; hence, it is expected to have lower concentration levels of SEM compared with this study that was conducted in heavily industrialized area.

\section{Assessment of sediment toxicity}

With a deep comprehension of metal contamination, it is widely accepted that the concentration of metals in the sediments alone is not enough for the assessment of bioavailability/ toxicity or contamination conditions throughout sediments (Long et al. 1995; Luoma 1989). It has been shown that the AVS model can be utilized to determine the level of contamination in sediments of freshwater and seawater (Ankley 1996; Di Toro et al. 1990). USEPA (2004b) suggested one criterion for evaluating the sediment toxicity. Based on this criterion, each sample can fall into one of the following three tiers: tier 1 , related adverse effects on aquatic life is probable when SEM-AVS > 5 (unit: $\mu \mathrm{mol}$ g); tier 2, related adverse effects on aquatic life are possible when $0<\mathrm{SEM}-\mathrm{AVS}<5$, and tier 3 , no indication of related adverse effects when SEM-AVS $<0$.

According to the this version of AVS-SEM model, the sediment at stations IST7 and UST10 in autumn and IST5 in spring belonged to tier 3 and almost had no adverse effect on the aquatic life; the sediment at stations IST1, IST3, IST8-10, UST1-9, and UST11 in autumn and stations IST3, IST7-9, UST1-9, and UST1-11 in spring belonged to tier 2 and had possible adverse effect on the aquatic life, and the sediments of other stations including IST2 and IST4-6 in autumn and IST1, IST2, IST4, IST6, and IST10 in spring belonged to tier 1 and have probable adverse effects on the aquatic life (Tables 4 and 5).

Although, not all the sediments in tiers 2 and 3 can cause increased toxicity because there are many other metal-binding phases such as TOC in sediments (Brix et al. 2010; Burton et al. 2005; De Jonge et al. 2012a, b; Di Toro et al. 2005), but complementary assessment approaches were used to assess the adverse biological effects of SEM considering the TOC concentrations in the sediments (USEPA 2005a; Di Toro et al. 2005). These approaches have also a three tier. According to approach proposed by USEPA (2005a), when (SEM-AVS) $/ f_{\text {OC }}>3000$ (on a molar basis), adverse effects may be expected (tier 1); when (SEM-AVS) $/ f_{\text {OC }}=130$ to 3000 , adverse effects are uncertain (tier 2); and when (SEM-AVS) $/ f_{\text {OC }}<130$, adverse effects are not expected (tier 3) (Table 4), but according to approach proposed by Di Toro et al. (2005), when (SEM-AVS)/ $f_{\text {OC }}>3400$ (on a molar basis), adverse effects may be expected (tier 1); when (SEM-AVS) $/ f_{\text {OC }}=150$ to 3400 , adverse effects are uncertain (tier 2); and when (SEM-AVS) $/ f_{\mathrm{OC}}<150$, adverse effects are not expected (tier 3) (Table 4).

The mentioned approaches above all have been used in this research, as have been listed in Table 4. Figures 6 and 7 depict the spatial distribution of SEM-AVS and (SEM-AVS) $/ f_{\text {OC }}$ in the coastal sediments in the harbor of Asaluyeh. According to this criterion, 4 stations $(\sim 20 \%)$ in autumn and 10 stations $(\sim 47 \%)$ in spring fell in tier 3 , which have no adverse effect; 17 stations $(\sim 80 \%)$ in autumn and 11 stations $(\sim 53 \%)$ in spring fell in tier 2, which have uncertain adverse effect; and no station fell in tier 1 in both seasons, which means that no stations have expected adverse effects.

This study illustrated that biotoxic degree of trace metals may change from season to season. There are several parameters affecting the levels and biotoxicity of trace metals in sediments. It appeared that seasonal variations of biotoxicity in this study is attributed to two reasons including (1) industrial effluents which can cause great heavy metal pollution (De Jonge et al. 2012a) and (2) floods and storms during rainy period that can lead to release back from insoluble metal sulfides in sediments to water (Prica et al. 2008; Van Den Berg et al. 1999).

It has been proved that AVS-SEM model is an appropriate ecological risk assessment approach, although it has some deficiencies and shortages. Some researchers have displayed that benthic organism can accumulate metals in their body, even when SEM-AVS $<0$, since benthic organism eats sediment particles as their major food source disregarding AVS concentration level (De Jonge et al. 2009, 2010; Lee et al. $2000 a, b)$. AVS values may vary when environmental 
Table 5 The comparison of metal concentrations in the coastal sediment in Asaluyeh harbor with the sediment quality guidelines

\begin{tabular}{|c|c|c|c|c|c|c|c|}
\hline & & $\mathrm{Zn}(\mu \mathrm{mol} / \mathrm{g})$ & $\mathrm{Cu}(\mu \mathrm{mol} / \mathrm{g})$ & $\mathrm{Pb}(\mu \mathrm{mol} / \mathrm{g})$ & $\mathrm{Ni}(\mu \mathrm{mol} / \mathrm{g})$ & $\mathrm{Cd}(\mathrm{nmol} / \mathrm{g})$ & Reference \\
\hline \multirow[t]{2}{*}{ This study } & Range & $0.18-11.88$ & $0.11-5.99$ & $0.01-1.09$ & $0.0009-0.88$ & $0.08-4.6$ & - \\
\hline & Mean & 4.51 & 2.02 & 0.385 & 0.23 & 2.61 & - \\
\hline \multirow[t]{2}{*}{ *SQGs of USA } & Effects range low (ERL) & 2.294 & 0.535 & 0.225 & 0.356 & 10.675 & $\begin{array}{l}\text { (Buchman 2008; } \\
\quad \text { Long et al. 1995) }\end{array}$ \\
\hline & Effect range median (ERM) & 6.271 & 4.249 & 1.052 & 0.879 & 85.401 & \\
\hline \multirow[t]{3}{*}{ SQGs of China } & The first class & 2.294 & 0.551 & 0.290 & - & 4.448 & (SOAPRC 2002) \\
\hline & The second class & 5.353 & 1.574 & 0.627 & - & 13.344 & \\
\hline & The third class & 9.177 & 3.148 & 1.207 & - & 44.480 & \\
\hline \multirow{2}{*}{$\begin{array}{l}\text { SQGs of } \\
\text { Australian and } \\
\text { New Zealand }\end{array}$} & Threshold effects level (TEL) & 1.897 & 0.294 & 0.146 & 0.271 & 6.049 & (Hübner et al. 2009) \\
\hline & Probable effect levels (PEL) & 4.145 & 1.700 & 0.541 & 0.729 & 37.452 & \\
\hline
\end{tabular}

*Sediment Quality Guidelines

conditions (such as $\mathrm{pH}$, Eh, oxygen content, etc.) change, and then, sediments without toxicity may generate toxicity. It appeared that portions of sulfides determined as AVS might be oxidized during the separation by suspension and can release back heavy metals into the water column. Thus, using this approach to metal remobilization researches would be suitable just in the case that sulfides are not oxidized during the separation by suspension (Di Toro et al. 1990; Durán et al. 2012; Zhuang and Gao 2013). The severe anoxic condition may cause the death of fishes, shellfishes, and other organisms such as benthic organisms (Zhuang and Gao 2013). At sampling period of this study, some dead organisms (fish or shellfish) were observed at the stations IST5, IST7, and IST9 where very low levels of redox potential (Eh) were found. However, there was no high heavy metal concentration based on AVS-SEM approach at these sampling stations. Sulfide ions derived from AVS can react with hydrogen ions to generate $\mathrm{H}_{2} \mathrm{~S}$ that has a severe neurotoxicity and can cause toxic effects on aquatic organisms and even on humans. $\mathrm{H}_{2} \mathrm{~S}$ can also cause corrosion in industrial equipment, pipelines, ships, and waterfront constructions (Jack et al. 1992; Kim and Kim 2001). Heavy metals can be reacted with AVS to decrease their biotoxicity, although AVS of extremely high content is also detrimental to aquatic life ( $\mathrm{Li}$ et al. 2014a). AVS has often high values in the environment with reductive status and high organic matter, because AVS is mostly generated by sulfate reduction in the metabolism of SRB that are anaerobic bacteria (Myhr et al. 2002; Wang et al. 2004). Regarding former cases mentioned, the method of AVS-SEM is not singly sufficient; hence, we compared findings of this study with several sediment quality guidelines of different countries to target more efficient evaluation of sediment quality that attended in following section.

\section{Comparison the SEM component values with the sediment quality guidelines}

Due to the lack of sediment quality standards in Iran, we compared the sediment values with the sediment quality standards of other countries. The comparison of the SEM components values with the sediment quality guidelines of some countries, such as Australia and New Zealand (Hübner et al. 2009), USA (Buchman 2008; Long et al. 1995), and China (SOAPsRoC. 2002), are given in Table 5. The findings display that except for SEM-Cd and SEM-Ni in some stations, heavy metal levels are relatively at high levels in most of the stations. Generally, SEM-Zn contamination is more obvious than others. As indicated in Fig. 8 and Table 5, the concentrations of SEM-Zn in stations of IST1, IST3, and IST5 (in spring) and stations of IST1 to IST5 (in winter) exceeded the third class (SQGs of China), the effect range median (ERM, SQGs of USA), and probable effect levels (PEL, SQGs of Australian and New Zealand). All these stations were located in the industrial area. In other stations of industrial area, the concentrations of SEM-Zn exceeded the threshold effects level (TEL) in SQGs of Australian and New Zealand, whereas between the urban stations, the concentrations of SEM-Zn only in UST16 (in both seasons) were above the TEL of Australian and New Zealand SQGs. Moreover, SEM-Cu and SEM-Pb concentrations in most of the industrial stations exceeded the mentioned SQGs but in the urban stations were below the SQGs. It should be noted that all the stations with exceeded concentrations of heavy metal related to the above guidelines were located in the industrial area; however, the UST16 (located in aquaculture zones and mouth of Khoor River) was the only station in the urban area that heavy metal concentrations exceeded the mentioned standards. 
Generally, the anthropogenic pollution origins of the marine environment are divided into four following classes: class 1 , discharged wastewater and garbage; class 2, pollutants brought by the upstream river; class 3 , aquaculture zone pollutants; and class 4, docks, boats, and ship pollutants (Li et al. 2014a). As environmental and coastal management has been not considered in the harbor of Asaluyeh, generated wastewater and garbage in coastal cities have been thrown into the sea, even worse, some hazardous solid waste have been discharged into the marine waters. Moreover, heavy metals contained in discarded batteries are remarkable, including batteries mixed with solid waste and batteries utilized in the boats and ships and may enter marine environment (Guo and Huang 2006). In the past decades, the recycling of battery has not been implemented yet in Asaluyeh harbor and many of the scrap batteries have been discharged directly into seawater, containing high load of heavy metals. Furthermore, organic matter of wastewater may accelerate the heavy metal accumulation in the sediments due to the coagulation, adsorption, and flocculation effects ( $\mathrm{Li}$ et al. 2013; Machado et al. 2004). In addition, the discharge of wastewater generated by intensive aquaculture zone and shrimp ponds around the Asaluyeh marines that have high levels of organic matters, nutrients, and suspended solids (Burford et al. 2003) may also contribute to the metal concentrations in studied areas.

\section{Conclusions}

In present study, we determined the concentration levels of heavy metals including $\mathrm{Cd}, \mathrm{Cu}, \mathrm{Ni}, \mathrm{Pb}$, and $\mathrm{Zn}$ in the marine sediments throughout the harbor of Asaluyeh based on AVS and SEM analysis as well as we evaluated the spatial distribution of heavy metals and their potential toxicity and ecological risk. The results demonstrated the evident differences in the levels of AVS and SEMs between the sediments from industrial and urban areas in Asaluyeh harbor. Due to the impact of human activities, AVS and SEM concentrations in the industrial locations were significantly higher than the urban locations. The AVS was positively correlated to SEM in both seasons of autumn and spring, which denoted that AVS was an important carrier of SEM. There was no significant correlation between AVS concentrations in different seasons, whereas SEM concentrations in the urban sediments showed significant variation during two sampling periods. Significant positive correlations were observed between all ingredients of SEM in pairs, which showed that examined metals might have common natural and anthropogenic origins. $\mathrm{Zn}$ was the predominant component of SEM, while the corresponding value for $\mathrm{Cd}$, much more toxic ingredient, was less than $1 \%$, and the levels of SEM components increased in the order of $\mathrm{Cd}<\mathrm{Pb} \ll$ $\mathrm{Ni} \ll \mathrm{Cu} \ll \mathrm{Zn}$. According to USEPA criteria (2005), some of the coastal sediments in the harbor of Asaluyeh (20 and $18 \%$ in the industrial and urban areas, respectively) had expected adverse biological effects, while most stations ( 80 and $82 \%$ in the industrial and urban areas, respectively) had uncertain adverse effects, and there was no station without expected adverse effects in this work. Finally, it should be said that it is necessary to perform further sophisticated studies on monitoring all kind of pollutants and micropollutants as well as implement an integrated management of marine and coastal environment in the region of the Persian Gulf.

Acknowledgments This work was conducted as part of the sediment quality assessment (SQA) to study the "acid-volatile sulfide (AVS) and simultaneously extracted metals (SEMs), dibenzo-p-dioxins (PCDDs), polychlorinated dibenzofurans (PCDFs), polybrominated diphenyl ethers (PBDEs), and dioxin-like polychlorinated biphenyls (dl-PCBs) concentrations and their regional characteristics, possible sources, and potential toxicity in coastal sediments from urban, semi-industrial, and industrial areas of Asaluyeh Harbor, Iran". The authors are grateful to the Bushehr University of Medical Sciences for financially and technically supporting this research (Grant No. 1500).

\section{References}

Allen HE, Fu G, Deng B (1993) Analysis of acid-volatile sulfide (AVS) and simultaneously extracted metals (SEM) for the estimation of potential toxicity in aquatic sediments. Environ Toxicol Chem 12: $1441-1453$

Ankley GT (1996) Evaluation of metal/acid-volatile sulfide relationships in the prediction of metal bioaccumulation by benthic macroinvertebrates. Environ Toxicol Chem 15:2138-2146

Asami H, Aida M, Watanabe K (2005) Accelerated sulfur cycle in coastal marine sediment beneath areas of intensive shellfish aquaculture. Appl Environ Microbiol 71:2925-2933

Azin R, Mosleh AM (2010) Corporate social responsibility related to oil, gas and petrochemical industry-case study: Assaluyeh, Iran. In: SPE International Conference on Health, Safety and Environment in oil and gas exploration and production. Society of petroleum engineers

Becking LB, Kaplan IR, Moore D (1960) Limits of the natural environment in terms of $\mathrm{pH}$ and oxidation-reduction potentials. J Geol 68: 243-284

Berner RA (1963) Electrode studies of hydrogen sulfide in marine sediments. Geochim Cosmochim Acta 27:563-575

Berry W et al (1996) Predicting the toxicity of metal-spiked laboratory sediments using acid-volatile sulfide and interstitial water normalizations. Environ Toxicol Chem 15:2067-2079

Brix KV, Keithly J, Santore RC, DeForest DK, Tobiason S (2010) Ecological risk assessment of zinc from stormwater runoff to an aquatic ecosystem. Sci Total Environ 408:1824-1832

Brouwer H, Murphy TP (1994) Diffusion method for the determination of acid-volatile sulfides (AVS) in sediment. Environ Toxicol Chem 13: $1273-1275$

Buchman MF (2008) NOAA screening quick reference tables office of response and restoration division. National Oceanic and Atmospheric Administration, Seattle, $\mathrm{p} 2$

Burford MA et al (2003) A synthesis of dominant ecological processes in intensive shrimp ponds and adjacent coastal environments in NE Australia. Mar Pollut Bull 46:1456-1469

Burton GA et al (2005) Field validation of sediment zinc toxicity. Environ Toxicol Chem 24:541-553 
Calmano W, Hong J, Förstner U (1993) Binding and mobilization of heavy metals in contaminated sediments affected by $\mathrm{pH}$ and redox potential

Campana O, Rodríguez A, Blasco J (2005) Bioavailability of heavy metals in the Guadalete River Estuary (SW Iberian Peninsula). Cienc Mar 31(1B): 135-147

Campana O, Rodríguez A, Blasco J (2009) Identification of a potential toxic hot spot associated with AVS spatial and seasonal variation. Arch Environ Contam Toxicol 56:416-425

Casas AM, Crecelius EA (1994) Relationship between acid volatile sulfide and the toxicity of zinc, lead and copper in marine sediments. Environ Toxicol Chem 13:529-536

Castro HF, Williams NH, Ogram A (2000) Phylogeny of sulfate-reducing bacteria. FEMS Microbiol Ecol 31:1-9

Celino JJ, de Oliveira OMC, Hadlich GM, de Souza Queiroz AF, Garcia KS (2008) Assessment of contamination by trace metals and petroleum hydrocarbons in sediments from the tropical estuary of Todos os Santos Bay Brazil. Braz J Geol 38:753-760

Cesar A, Pereira CDS, Santos AR, Abessa DMS, Fernández N, Choueri RB, DelValls TA (2006) Ecotoxicological assessment of sediments from the Santos and São Vicente estuarine system-Brazil. Braz J Oceanogr 54:55-63

Chai M, Shen X, Li R, Qiu G (2015) The risk assessment of heavy metals in Futian mangrove forest sediment in Shenzhen Bay (South China) based on SEM-AVS analysis. Mar Pollut Bull. doi:10.1016/j. marpolbul.2015.05.057

Cooper DC, Morse JW (1998) Biogeochemical controls on trace metal cycling in anoxic marine sediments. Environ Sci Technol 32:327330

Davis J, Yarbrough H (1966) Anaerobic oxidation of hydrocarbons by Desulfovibrio desulfuricans. Chem Geol 1:137-144

De Jonge M, Dreesen F, De Paepe J, Blust R, Bervoets L (2009) Do acid volatile sulfides (AVS) influence the accumulation of sedimentbound metals to benthic invertebrates under natural field conditions? Environ Sci Technol 43:4510-4516

De Jonge M, Blust R, Bervoets L (2010) The relation between acid volatile sulfides (AVS) and metal accumulation in aquatic invertebrates: implications of feeding behavior and ecology. Environ Pollut 158:1381-1391

De Jonge M, Teuchies J, Meire P, Blust R, Bervoets L (2012a) The impact of increased oxygen conditions on metal-contaminated sediments part I: effects on redox status, sediment geochemistry and metal bioavailability. Water Res 46:2205-2214

De Jonge M, Teuchies J, Meire P, Blust R, Bervoets L (2012b) The impact of increased oxygen conditions on metal-contaminated sediments part II: effects on metal accumulation and toxicity in aquatic invertebrates. Water Res 46:3387-3397

De Lange H, Van Griethuysen C, Koelmans A (2008) Sampling method, storage and pretreatment of sediment affect AVS concentrations with consequences for bioassay responses. Environ Pollut 151:243-251

Di Toro DM, Mahony JD, Hansen DJ, Scott KJ, Hicks MB, Mayr SM, Redmond MS (1990) Toxicity of cadmium in sediments: the role of acid volatile sulfide. Environ Toxicol Chem 9:1487-1502

Di Toro DM et al (2005) Predicting sediment metal toxicity using a sediment biotic ligand model: methodology and initial application. Environ Toxicol Chem 24:2410-2427

Du Laing G, Rinklebe J, Vandecasteele B, Meers E, Tack F (2009) Trace metal behaviour in estuarine and riverine floodplain soils and sediments: a review. Sci Total Environ 407:3972-3985

Du H, Huang X, Huang H, Zheng B, Chen W (2011) The spatiotemporal distribution of acid-volatile sulfide (AVS) and sulfate-reducing bacteria (SRB) in the surface deposits at Shen'ao Bay. Trans Oceanol Limnol 5:85-93

Durán I, Sánchez-Marín P, Beiras R (2012) Dependence of Cu, Pb and Zn remobilization on physicochemical properties of marine sediments. Mar Environ Res 77:43-49
EPA (2010) Guidance on evaluating sediment contaminant results, division of surface water, standards and technical support section environmental protection agency

Fang T, Li X, Zhang G (2005) Acid volatile sulfide and simultaneously extracted metals in the sediment cores of the Pearl River Estuary, South China. Ecotoxicol Environ Saf 61:420-431

Feng L, Haiting W, Deli W (2004) Spatial distributions of heavy metals from the Laizhou Bay Littoral Wetland. Adv Mar Sci 22:486-492

Fernandes L, Nayak G, Ilangovan D, Borole D (2011) Accumulation of sediment, organic matter and trace metals with space and time, in a creek along Mumbai coast, India. Estuar Coast Shelf Sci 91:388399

Gan HY, Lin JQ, Liang K, Xia Z (2013) Selected trace metals (As, Cd and $\mathrm{Hg}$ ) distribution and contamination in the coastal wetland sediment of the northern Beibu Gulf, South China. Sea Mar Pollut Bull 66: $252-258$

Gao X, Chen C-TA (2012) Heavy metal pollution status in surface sediments of the coastal Bohai Bay. Water Res 46:1901-1911

Gao X, Li P, Chen C-TA (2013) Assessment of sediment quality in two important areas of mariculture in the Bohai Sea and the northern Yellow Sea based on acid-volatile sulfide and simultaneously extracted metal results. Mar Pollut Bull 72:281-288

Guo X, Huang C (2006) Distribution and source of heavy metal elements in sediments of Zhanjiang Harbor. J Trop Oceanogr 25:91-96

Hansen D et al (1996) Predicting the toxicity of metal-contaminated field sediments using interstitial concentration of metals and acid-volatile sulfide normalizations. Environ Toxicol Chem 15:2080-2094

Hinkey LM, Zaidi BR (2007) Differences in SEM-AVS and ERM-ERL predictions of sediment impacts from metals in two US Virgin Islands marinas. Mar Pollut Bull 54:180-185

Hou D, He J, Lü C, Ren L, Fan Q, Wang J, Xie Z (2013) Distribution characteristics and potential ecological risk assessment of heavy metals $(\mathrm{Cu}, \mathrm{Pb}, \mathrm{Zn}, \mathrm{Cd})$ in water and sediments from Lake Dalinouer, China. Ecotoxicol Environ Saf 93:135-144

Hu N, Shi X, Liu J, Huang P, Yang G, Liu Y (2011) Distributions and impacts of heavy metals in the surface sediments of the Laizhou Bay. Adv Mar Sci 29:63-72

Hu N, Liu J, Huang P, Shi X, Zhu A, Ma D (2012) The distribution and risk assessment of metals in surface sediments of the Laizhou Bay in the Bohai Sea. Acta Oceanol Sin 34:92-100

Hübner R, Astin KB, Herbert RJ (2009) Comparison of sediment quality guidelines (SQGs) for the assessment of metal contamination in marine and estuarine environments. J Environ Monit 11:713-722

Huo W, Li Q, Ma X (2001) Study on acid-volatile sulfide (AVS) of sediment in mariculture region of Jiaozhou Bay. Sci Geogr Sin 21: 135-139

Ingersoll C et al (2002) Toxicity assessment of sediments from the Grand Calumet River and Indiana Harbor Canal in northwestern Indiana, USA. Arch Environ Contam Toxicol 43:156-167

Ip CC, Li X-D, Zhang G, Wai OW, Li Y-S (2007) Trace metal distribution in sediments of the Pearl River Estuary and the surrounding coastal area, South China. Environ Pollut 147:311-323

Jack R, Ringelberg D, White D (1992) Differential corrosion rates of carbon steel by combinations of Bacillus sp., Hafnia alvei and Desulfovibrio gigas established by phospholipid analysis of electrode biofilm. Corros Sci 33:1843-1853

Jiang W, Pohlmann T, Sündermann J, Feng S (2000) A modelling study of SPM transport in the Bohai Sea. J Mar Syst 24:175-200

Jiang Z, Ma Q, Wang X, Zhang Y (2005) Study on the AVS in surface sediment in the North Area of the Bohai Bay. Mar Environ Sci 24:6-8

Jingchun L, Chongling Y, Spencer KL, Ruifeng Z, Haoliang L (2010) The distribution of acid-volatile sulfide and simultaneously extracted metals in sediments from a mangrove forest and adjacent mudflat in Zhangjiang Estuary, China. Mar Pollut Bull 60:1209-1216 
Keene AF, Johnston SG, Bush RT, Burton ED, Sullivan LA (2010) Reactive trace element enrichment in a highly modified, tidally inundated acid sulfate soil wetland: East Trinity, Australia. Mar Pollut Bull 60:620-626

Kim J-G, Kim Y-W (2001) Cathodic protection criteria of thermally insulated pipeline buried in soil. Corros Sci 43:2011-2021

Lee B-G, Griscom SB, Lee J-S, Choi HJ, Koh C-H, Luoma SN, Fisher NS (2000a) Influences of dietary uptake and reactive sulfides on metal bioavailability from aquatic sediments. Science 287:282-284

Lee B-G, Lee J-S, Luoma SN, Choi HJ, Koh C-H (2000b) Influence of acid volatile sulfide and metal concentrations on metal bioavailability to marine invertebrates in contaminated sediments. Environ Sci Technol 34:4517-4523

Li F et al (2013) Ecological risks assessment and pollution source identification of trace elements in contaminated sediments from the Pearl River Delta, China. Biol Trace Elem Res 155:301-313

Li F et al (2014a) Coastal surface sediment quality assessment in Leizhou Peninsula (South China Sea) based on SEM-AVS analysis. Mar Pollut Bull 84:424-436

Li L, Wang X, Liu J, Shi X, Ma D (2014b) Assessing metal toxicity in sediments using the equilibrium partitioning model and empirical sediment quality guidelines: a case study in the nearshore zone of the Bohai Sea, China. Mar Pollut Bull 85:114-122

Li L, Wu H, van Gestel CA, Peijnenburg WJ, Allen HE (2014c) Soil acidification increases metal extractability and bioavailability in old orchard soils of Northeast Jiaodong Peninsula in China. Environ Pollut 188:144-152

Lin S, Huang K-M, Chen S-K (2002) Sulfate reduction and iron sulfide mineral formation in the southern East China Sea continental slope sediment. Deep-Sea Res I Oceanogr Res Pap 49:1837-1852

Liu J, Yan C, Macnair MR, Hu J, Li Y (2007) Vertical distribution of acidvolatile sulfide and simultaneously extracted metals in mangrove sediments from the Jiulong River Estuary, Fujian, China. Environ Sci Pollut Res Int 14:345-349

Long ER, MacDonald DD, Smith SL, Calder FD (1995) Incidence of adverse biological effects within ranges of chemical concentrations in marine and estuarine sediments. Environ Manag 19:81-97

Luoma SN (1989) Can we determine the biological availability of sediment-bound trace elements? Hydrobiologia 176:379-396

Machado W, Carvalho M, Santelli R, Maddock J (2004) Reactive sulfides relationship with metals in sediments from an eutrophicated estuary in Southeast Brazil. Mar Pollut Bull 49:89-92

Machado W, Santelli RE, Carvalho M, Molisani MM, Barreto RC, Lacerda LD (2008) Relation of reactive sulfides with organic carbon, iron, and manganese in anaerobic mangrove sediments: implications for sediment suitability to trap trace metals. J Coast Res 24: $25-32$

Mokhtarani B, Moghaddam MRA, Mokhtarani N, Khaledi HJ (2006a) Report: future industrial solid waste management in pars special economic energy zone (PSEEZ), Iran. Waste Manag Res 24:283-288

Mokhtarani BAMMR, Mokhtarani N, KhalediH J (2006b) Future industrial solid waste management in Pars Special Economic Energy Zone (PSEEZ), Iran. Waste Manag Res 24:1-6

Monikh FA, Safahieh A, Savari A, Doraghi A (2013) Heavy metal concentration in sediment, benthic, benthopelagic, and pelagic fish species from Musa Estuary (Persian Gulf). Environ Monit Assess 185: 215-222

Monikh FA, Maryamabadi A, Savari A, Ghanemi K (2015) Heavy metals' concentration in sediment, shrimp and two fish species from the northwest Persian Gulf. Toxicol Ind Health 31:554-565

Morgan B, Rate AW, Burton ED (2012) Trace element reactivity in FeSrich estuarine sediments: influence of formation environment and acid sulfate soil drainage. Sci Total Environ 438:463-476

Morita RY (1975) Psychrophilic bacteria. Bacteriol Rev 39:144-156

Morse JW, Rickard D (2004) Peer reviewed: chemical dynamics of sedimentary acid volatile sulfide. Environ Sci Technol 38:131A-136A
Mucha AP, Vasconcelos MTSD, Bordalo AA (2005) Spatial and seasonal variations of the macrobenthic community and metal contamination in the Douro estuary (Portugal). Mar Environ Res 60:531-550

Myhr S, Lillebø B-L, Sunde E, Beeder J, Torsvik T (2002) Inhibition of microbial $\mathrm{H} 2 \mathrm{~S}$ production in an oil reservoir model column by nitrate injection. Appl Microbiol Biotechnol 58:400-408

Nizoli EC, Luiz-Silva W (2012) Seasonal AVS-SEM relationship in sediments and potential bioavailability of metals in industrialized estuary, Southeastern Brazil. Environ Geochem Health 34:263-272

Nobi E, Dilipan E, Thangaradjou T, Sivakumar K, Kannan L (2010) Geochemical and geo-statistical assessment of heavy metal concentration in the sediments of different coastal ecosystems of Andaman Islands, India. Estuar Coast Shelf Sci 87:253-264

Oehm N, Luben T, Ostrofsky M (1997) Spatial distribution of acidvolatile sulfur in the sediments of Canadohta Lake, PA. Hydrobiologia 345:79-85

Poot A, Gillissen F, Koelmans A (2007) Effects of flow regime and flooding on heavy metal availability in sediment and soil of a dynamic river system. Environ Pollut 148:779-787

Prica M, Dalmacija B, Rončević S, Krčmar D, Bečelić M (2008) A comparison of sediment quality results with acid volatile sulfide (AVS) and simultaneously extracted metals (SEM) ratio in Vojvodina (Serbia) sediments. Sci Total Environ 389:235-244

Qiao S, Shi X, Zhu A, Liu Y, Bi N, Fang X, Yang G (2010) Distribution and transport of suspended sediments off the Yellow River (Huanghe) mouth and the nearby Bohai Sea. Estuar Coast Shelf Sci 86:337-344

Raj SM, Jayaprakash M (2008) Distribution and enrichment of trace metals in marine sediments of Bay of Bengal, off Ennore, southeast coast of India. Environ Geol 56:207-217

Simpson SL, Apte SC, Batley GE (1998) Effect of short-term resuspension events on trace metal speciation in polluted anoxic sediments. Environ Sci Technol 32:620-625

SOAPsRoC. S (2002) Marine sediment quality (GB 18668-2002) (in Chinese)

Soares H, Boaventura R, Machado A, Da Silva JE (1999) Sediments as monitors of heavy metal contamination in the Ave river basin (Portugal): multivariate analysis of data. Environ Pollut 105:311323

Spencer K, Dewhurst R, Penna P (2006) Potential impacts of water injection dredging on water quality and ecotoxicity in Limehouse Basin, River Thames, SE England, UK. Chemosphere 63:509-521

Sun WW, Wang DQ, Chen ZL, Bi CJ, Hu BB, Liu YL, Li JF, Xu SY (2009) Contents and spatial distributions of AVS and SEM in Wusong-Liuhe coastal sediments in Yangtze Estuary. Geochimica 38:140-146

USEPA (2001) Methods for collection, storage and manipulation of sediments for chemical and toxicological analyses: technical manual 2001 office of science \& technology, office of water: Washington, DC EPA-823-B-01002

USEPA (2004a) The incidence and severity of sediment contamination in surface waters of the United States (National Sediment Quality Survey EPA-823-R-04-007, 2nd edn. United States Environmental Protection Agency, Office of Science and Technology, Washington, DC

USEPA (2004b) The incidence and severity of sediment contamination in surface waters of the United States, National Sediment Quality Survey EPA 823-R-04-007, 2nd edn. US Environmental Protection Agency, Office of Water, Washington, DC

USEPA (2005a) Procedures for the derivation of equilibrium partitioning sediment benchmarks (ESBs) for the protection of benthic organisms: metal mixtures (Cadmium, Copper, Lead, Nickel, Silver, and Zinc) EPA-600-R-02-011. US Environmental Protection Agency, Office of Research and Development, Washington, DC

USEPA (2005b) Procedures for the derivation of equilibrium partitioning sediment benchmarks (ESBs) for the protection of benthic 
organisms: metal mixtures (Cadmium, Copper, Lead, Nickel, Silver, and Zinc) (EPA-600-R-02-011. United States Environmental Protection Agency, Office of Research and Development, Washington, DC

Van Den Berg GA, Loch JG, Van Der Heijdt LM, Zwolsman JJ (1999) Mobilisation of heavy metals in contaminated sediments in the river Meuse, The Netherlands. Water Air Soil Pollut 116:567-586

Van Griethuysen C, Gillissen F, Koelmans A (2002) Measuring acid volatile sulphide in floodplain lake sediments: effect of reaction time, sample size and aeration. Chemosphere 47:395-400

Van Griethuysen C, De Lange H, Van den Heuij M, De Bies S, Gillissen F, Koelmans A (2006) Temporal dynamics of AVS and SEM in sediment of shallow freshwater floodplain lakes. Appl Geochem 21:632-642

Wang F, Chapman PM (1999) Biological implications of sulfide in sediment - a review focusing on sediment toxicity. Environ Toxicol Chem 18:2526-2532

Wang C-y, Wang X-1 (2007) Spatial distribution of dissolved Pb, $\mathrm{Hg}, \mathrm{Cd}$, $\mathrm{Cu}$ and as in the Bohai Sea. J Environ Sci 19:1061-1066

Wang W, Li X, Wang J, Xu H, Wu J (2004) Influence of biofilms growth on corrosion potential of metals immersed in seawater. Mater Corros 55:30-35

Wijsman JW, Middelburg JJ, Herman PM, Böttcher ME, Heip CH (2001) Sulfur and iron speciation in surface sediments along the northwestern margin of the Black Sea. Mar Chemistry 74:261-278
Wu Q, Ma Q, Wang J, Jiang Z, Wang X (2007) The AVS in surface sediment of near sea area of Huanghe Estuary. Mar Environ Sci 26:126-129

Yang YQ, Chen FR, Zhang L, Liu JS, Wu SJ, Kang ML (2012) Comprehensive assessment of heavy metal contamination in sediment of the Pearl River Estuary and adjacent shelf. Mar Pollut Bull 64:1947-1955

Yokoyama H, Inoue M, Abo K (2004) Estimation of the assimilative capacity of fish-farm environments based on the current velocity measured by plaster balls. Aquaculture 240:233-247

Younis AM, El-Zokm GM, Okbah MA (2014) Spatial variation of acidvolatile sulfide and simultaneously extracted metals in Egyptian Mediterranean Sea lagoon sediments. Environ Monit Assess 186: 3567-3579

Yu K-C, Tsai L-J, Chen S-H, Ho S-T (2001) Chemical binding of heavy metals in anoxic river sediments. Water Res 35:4086-4094

Zhuang W, Gao X (2013) Acid-volatile sulfide and simultaneously extracted metals in surface sediments of the southwestern coastal Laizhou Bay, Bohai Sea: concentrations, spatial distributions and the indication of heavy metal pollution status. Mar Pollut Bull 76:128-138

Zimmerman AR, Canuel EA (2000) A geochemical record of eutrophication and anoxia in Chesapeake Bay sediments: anthropogenic influence on organic matter composition. Mar Chem 69:117-137 